\title{
Revised methane emissions factors and spatially distributed annual carbon fluxes for global livestock
}

\author{
Julie Wolf ${ }^{1 *}\left(\mathbb{D}\right.$, Ghassem R. Asrar ${ }^{2}$ and Tristram O. West ${ }^{2,3}$
}

\begin{abstract}
Background: Livestock play an important role in carbon cycling through consumption of biomass and emissions of methane. Recent research suggests that existing bottom-up inventories of livestock methane emissions in the US, such as those made using 2006 IPCC Tier 1 livestock emissions factors, are too low. This may be due to outdated information used to develop these emissions factors. In this study, we update information for cattle and swine by region, based on reported recent changes in animal body mass, feed quality and quantity, milk productivity, and management of animals and manure. We then use this updated information to calculate new livestock methane emissions factors for enteric fermentation in cattle, and for manure management in cattle and swine.

Results: Using the new emissions factors, we estimate global livestock emissions of $119.1 \pm 18.2 \mathrm{Tg}$ methane in 2011; this quantity is $11 \%$ greater than that obtained using the IPCC 2006 emissions factors, encompassing an $8.4 \%$ increase in enteric fermentation methane, a $36.7 \%$ increase in manure management methane, and notable variability among regions and sources. For example, revised manure management methane emissions for 2011 in the US increased by 71.8\%. For years through 2013, we present (a) annual livestock methane emissions, (b) complete annual livestock carbon budgets, including carbon dioxide emissions, and (c) spatial distributions of livestock methane and other carbon fluxes, downscaled to $0.05 \times 0.05$ degree resolution.

Conclusions: Our revised bottom-up estimates of global livestock methane emissions are comparable to recently reported top-down global estimates for recent years, and account for a significant part of the increase in annual methane emissions since 2007. Our results suggest that livestock methane emissions, while not the dominant overall source of global methane emissions, may be a major contributor to the observed annual emissions increases over the 2000s to 2010s. Differences at regional and local scales may help distinguish livestock methane emissions from those of other sectors in future top-down studies. The revised estimates allow improved reconciliation of top-down and bottom-up estimates of methane emissions, will facilitate the development and evaluation of Earth system models, and provide consistent regional and global Tier 1 estimates for environmental assessments.
\end{abstract}

Keywords: Methane emissions, Carbon monitoring system, Livestock, Enteric fermentation, Manure management, Greenhouse gas, Carbon dioxide, IPCC

\section{Background}

Livestock play an important role in agricultural carbon (C) cycling and are associated with large annual greenhouse gas emissions $[1,2]$. The IPCC $[3,4]$ provides

*Correspondence: julie.wolf2@ars.usda.gov; thejuliewolf@gmail.com 1 USDA-ARS, Adaptive Cropping Systems Laboratory, 10300 Baltimore Ave., Building 001, Room. 342, BARC-WEST, Beltsville, MD 20705, USA Full list of author information is available at the end of the article guidelines for bottom-up estimation of livestock emissions based on inventory, which have been employed at the global $[5,6]$ and national levels (e.g. annual reports to the United Nations Framework Convention on Climate Change). In inventory-based estimation of national livestock methane $\left(\mathrm{CH}_{4}\right)$ emissions, annual standing populations of each animal type are multiplied by speciesand region-specific emissions factors to obtain annual 
emissions quantities. The emissions factors are derived using sets of mathematical formulae with inputs that vary depending on regional livestock qualities and management (e.g. feed intake quantity and quality; milk production quantity; amount of energy used for growth, draft work, foraging, and pregnancy; and utilization of various manure management systems) [4].

The input information in the IPCC 2006 guidelines is based on literature reflecting earlier decades; e.g. sources listed for tables in Annexes 10.A1 and 10A.2 in [4] were published between 1976 and 2004, with most from the 1980s and 1990s. In at least some regions, this information no longer reflects the state of livestock. For example, in many industrialized or industrializing nations, management of manure in pits or lagoons, instead of on pasture or cropland, has become more prevalent $[7,8]$ and animals perform less draft work [9] than in earlier decades. For example, IPCC 2006 guidelines and recent publications based on them [10,11] consider $12 \%$ of US dairy cattle manure to be managed in anaerobic lagoons, while more recent data from the US EPA [12] suggest that anaerobic lagoons are now much more widely used. Because $\mathrm{CH}_{4}$ emissions from anaerobic lagoons are calculated to be nearly twice the magnitude of those from aerobic systems per unit of manure input, these changes must be taken into account in new bottom-up inventories.

The IPCC 2006 default information is used to calculate bottom-up $\mathrm{CH}_{4}$ emissions in important global earth system simulation studies and environmental assessments $[13,14]$. For example, in addition to reports from the IPCC [15], the US Environmental Protection Agency's report on global emissions [16], IIASA's greenhouse gas and air pollution interactions and synergies (GAINS) model [17], and the emissions database for global atmospheric research (EDGAR) [18] use IPCC 2006 default information, although the latter modifies cattle inputs based on carcass weight or milk productivity. IIASA's RAINS model, an earlier source of global $\mathrm{CH}_{4}$ emissions used in a recent longer-term study along with EDGAR and EPA data [13], is based on IPCC 1996 [3] emissions factors [19]. Recent top-down estimates for the US, however, suggest that even revised methods based on IPCC guidelines underestimate livestock $\mathrm{CH}_{4}$ emissions in recent years at the national or state level [20-23]. Additionally, since 2007, global atmospheric concentrations of $\mathrm{CH}_{4}$ began increasing again after several stable years, and the ${ }^{13} \mathrm{C}$ isotopic ratio of atmospheric $\mathrm{CH}_{4}$ concurrently become more negative; these changes may indicate increasing $\mathrm{CH}_{4}$ emissions from biogenic sources such as wetlands, rice paddies, and/or livestock in various global regions [24-28]. These changes and discrepancies illustrate the need for updated livestock $\mathrm{CH}_{4}$ emissions coefficients for bottom-up inventories.
Many factors are likely to impact recent livestock $\mathrm{CH}_{4}$ emissions quantities, such as the proportion of animals in large animal feeding operations that use various manure management systems; animal traits, such as body mass or productivity, which have changed with animal breeding and increased use of improved breeds; and animal feed quality and quantity, which may change over sub-annual and longer time periods. Here, we re-evaluated inputs used to calculate IPCC tier $1 \mathrm{CH}_{4}$ emission factors for (1) enteric fermentation emissions in dairy cows and in meat/other cattle and (2) manure management emissions in dairy cows, meat/other cattle, and swine.

\section{Methods}

\section{Revision of annual, per-animal $\mathrm{CH}_{4}$ emissions factors and other livestock $\mathrm{C}$ fluxes}

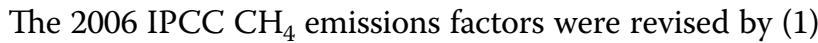
collecting updated regional input information (Tables 1 , 2 ) and (2) following the Tier 2 equations for enteric fermentation and manure management $\mathrm{CH}_{4}$ emissions [4] with the updated inputs. This resulted in new emissions factors suitable for Tier 1 bottom-up inventory based estimates. To revise enteric fermentation emissions factors for lactating dairy cows, for example, Equations 10.2, 10.3, 10.4, 10.6, 10.8, 10.11, 10.13, 10.14, 10.16, 10.18b, and 10.21 were used with input from Tables 10.2, 10.4, 10.5, 10.8, 10.12, 10.A.1 [4] (Table 1). To revise manure $\mathrm{CH}_{4}$ emissions factors for dairy cows, meat/other cattle, and swine, Equations 10.23 and 10.24 were used with input from Tables 10.17, 10A-4, 10A-5, 10A-7, and 10A-8 [4] (Table 2). Some information on total dry matter intake and/or gross energy intake and manure production are also provided by IPCC; these quantities were also updated and used to create complete livestock $C$ budgets (see below). Manure production for cattle was estimated from updated regional animal body weights, assuming that dairy cattle produce $2205 \mathrm{~kg}$ manure dry matter per animal unit per year, and meat/other cattle produce $1510 \mathrm{~kg}$ manure dry matter per animal unit per year [29]. Manure production for swine was estimated using IPCC 1996 regional swine body weight and manure production information [3] along with revised (recent) regional body weights, based on the approximation that intake scales with a three-fourths fractional exponent of body mass [30]:

$\begin{aligned} \text { manure-production }_{\text {revised }}= & \text { manure-production }_{1996 \mathrm{IPCC}} \\ & \times\left[\text { weight }_{\text {revised }} / \text { weight }_{1996 \mathrm{IPCC}}\right]^{0.75}\end{aligned}$

To evaluate our bottom-up approach to estimating $C$ stocks and fluxes, the equations and default inputs were first used to recalculate the IPCC $2006 \mathrm{CH}_{4}$ emissions factors. Literature search results were then used to revise inputs and recalculate these equations. 


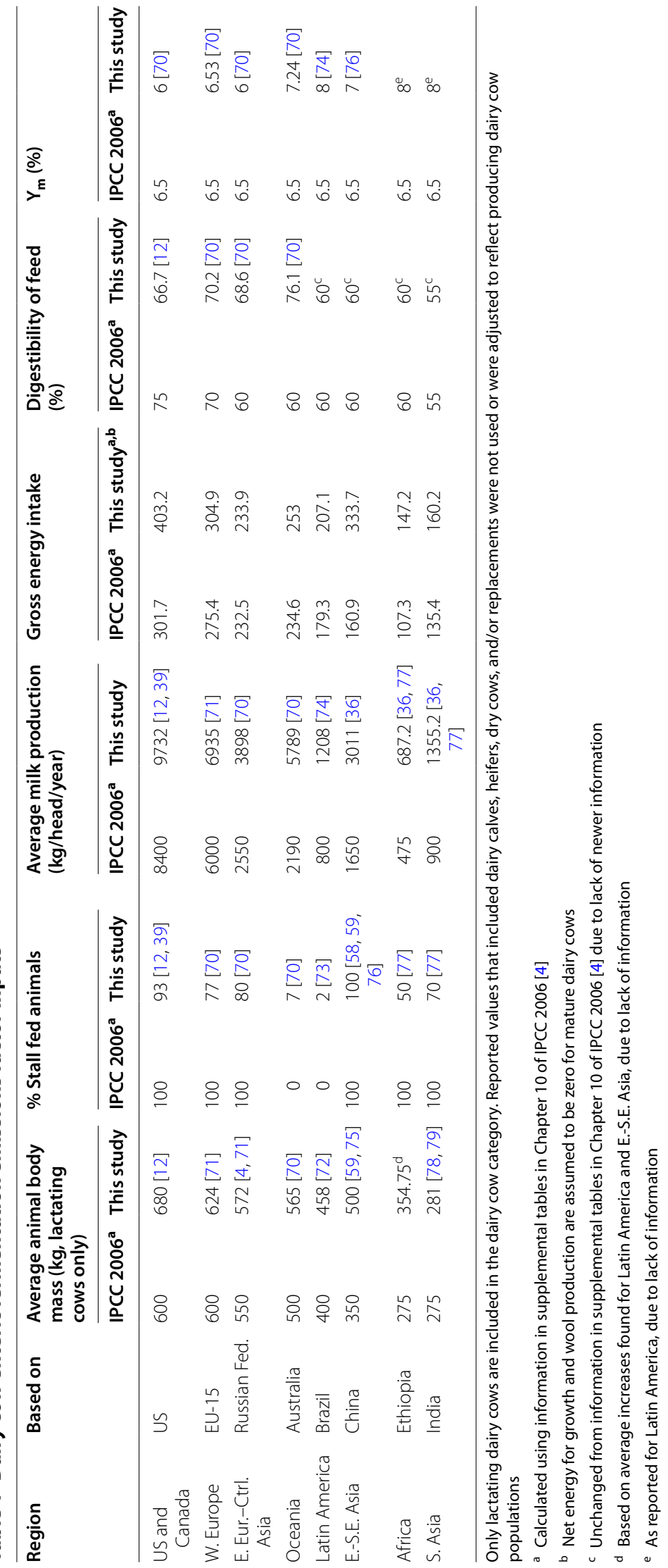




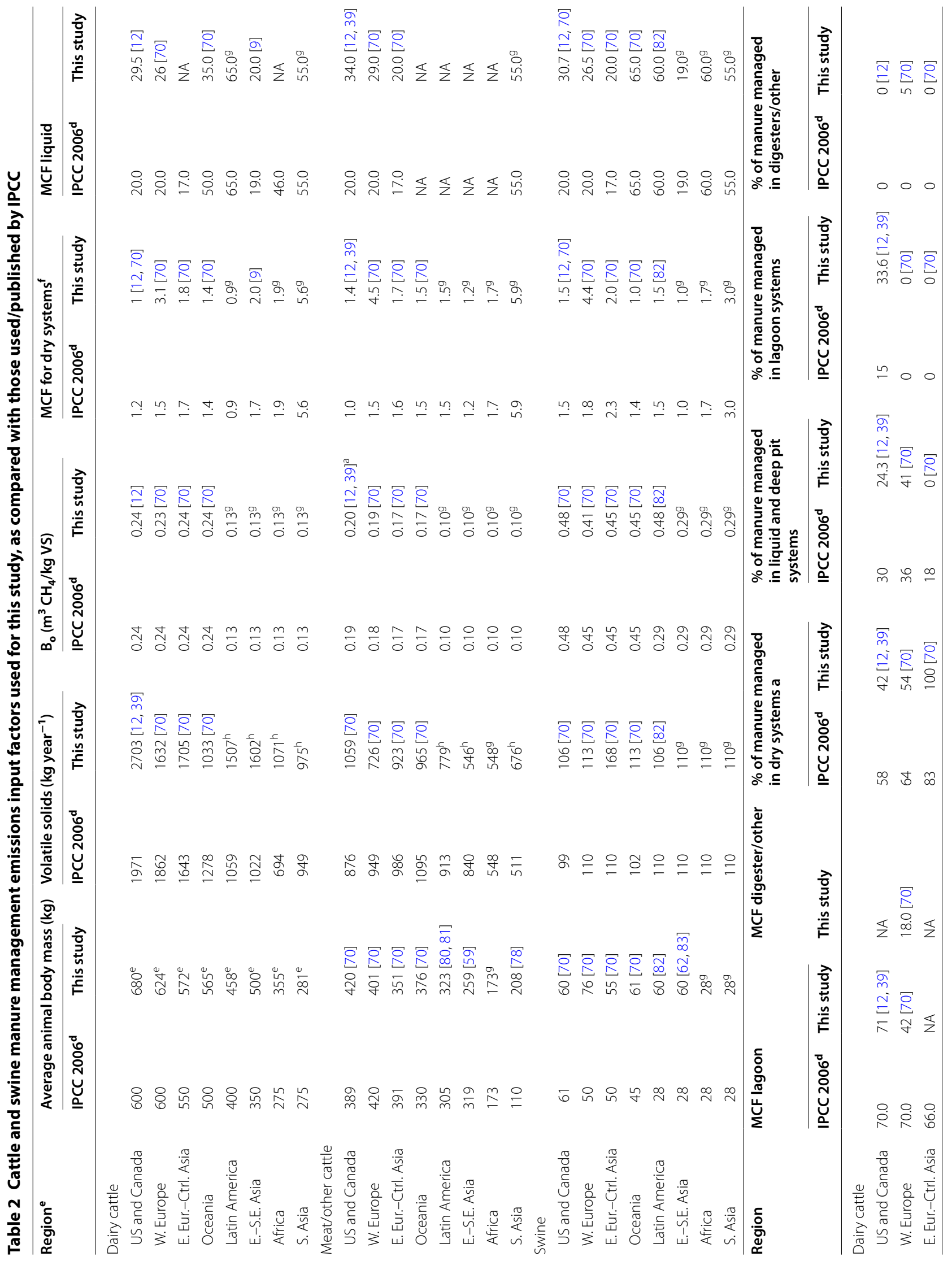




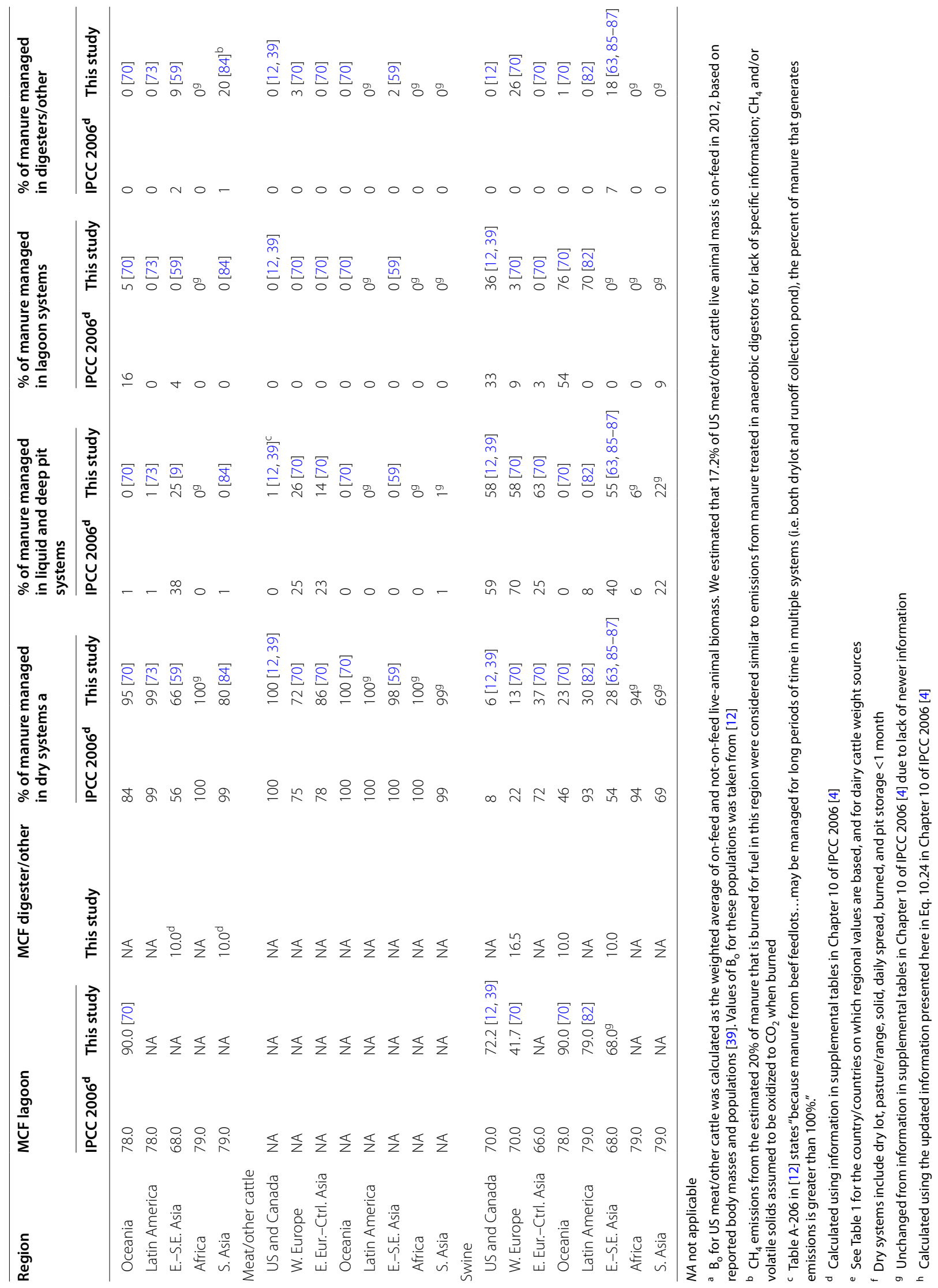


For dairy cow enteric fermentation $\mathrm{CH}_{4}$ emissions factors, revisions focused on changes in mature animal weight, percent of animals that are stall fed as opposed to grazing/ranging for feed, annual milk productivity, changes in total feed intake, and on reported values of $\mathrm{Y}_{\mathrm{m}}$ (the $\mathrm{CH}_{4}$ conversion factors for feed energy intake during enteric fermentation). For these calculations, we assumed that mature lactating dairy cows do not gain or lose weight, so that net energy for growth takes a value of zero. For enteric fermentation $\mathrm{CH}_{4}$ emissions from meat/other cattle, we use recently reported emissions factors from national UNFSCCC reports where available, and where such information was not available, we calculated revised factors based on changes in animal body weight only. This approach was taken due to the complexity and variability in important management factors for meat cattle, particularly in industrialized systems (e.g. type of diet provided, timing of placement from pasture to feedlot, slaughter age and weight).

For manure management $\mathrm{CH}_{4}$ emissions factors, revisions focused on changes in animal weight at slaughter, changes in total feed intake and feed digestibility, and changes in the percentage of manure managed in various manure management systems (e.g. deposited on pasture, drylot storage, short-term pit storage, longterm anaerobic lagoon treatment), and MCFs (methane conversion factors, the $\mathrm{CH}_{4}$ conversion factors for manure volatile solids during manure storage and/ or treatment) for different manure management systems at various temperatures. Because of the difficulty in obtaining recent information for all regions of the world, we did not revise $\mathrm{B}_{\mathrm{o}}$ (the amount of $\mathrm{CH}_{4}$ produced per quantity of manure volatile solids). Manure management $\mathrm{CH}_{4}$ emissions factors were revised for (1) lactating dairy cattle; (2) meat/other cattle (encompassing meat and dairy calves and heifers and all other cohorts of non-lactating cattle grown for slaughter, replacement, breeding, or other purposes, weighted using mean weights and reported population cohorts), and (3) swine (encompassing farrowing sows, nursing piglets, and feeders, weighted using mean weights and reported population cohorts). For meat/other cattle in the US, where in recent years animals weighed $27-45 \mathrm{~kg}$ at birth [31], were weaned at $\sim 260 \mathrm{~kg}$ [31], were placed on feedlots at $\sim 317 \mathrm{~kg}$ [32], and were slaughtered at $\sim 610 \mathrm{~kg}$ [33], the amounts of manure managed on pasture and on feedlot were weighted by average cohort masses accordingly.

\section{Uncertainty analysis}

We employed IPCC 2006 Uncertainty Approach I: Propagation of Error [34] to arithmetically combine the uncertainties associated with livestock carbon fluxes of interest:

Where uncertain quantities are to be combined by multiplication, the standard deviation of the sum will be the square root of the sum of the squares of the standard deviations of the quantities that are added, with the standard deviations all expressed as coefficients of variation, which are the ratios of the standard deviations to the appropriate mean values...Where uncertain quantities are to be combined by addition or subtraction, the standard deviation of the sum will be the square root of the sum of the squares of the standard deviations of the quantities that are added with the standard deviations all expressed in absolute terms ... [34]

When the uncertainties being combined can be considered independent, their standard deviations or coefficients of variation are added in quadrature (i.e. the square root of the sum of the squares of each standard deviation or coefficient of variation) [35]. This has the effect of reducing overall propagated uncertainty. We added in quadrature when propagating uncertainties within a livestock type, because we independently assembled separate estimates of the various carbon fluxes and their uncertainties (e.g. intake, manure production, milk production, $\mathrm{CH}_{4}$ emissions) except for $\mathrm{CO}_{2}$, which is calculated by subtraction. We then used these uncertainties to calculate fractional standard deviations (equal to the coefficient of variation, the standard deviation divided by the mean value) for each per-animal carbon flux quantity in each global region. However, when combining uncertainties across livestock types within a nation or from multiple nations to the regional or global level, the uncertainties were simply added (not in quadrature), because these estimates are not independent [35]-i.e. the livestock in all nations within a region share the same carbon flux estimates, emissions coefficients, and uncertainties, and all livestock within a nation share many regional attributes. Using the arithmetic sum, as opposed to adding in quadrature, results in larger uncertainties, which may be considered more conservative.

Uncertainty on all non- $\mathrm{CH}_{4}$ quantities is derived from the coefficients of variation (the standard deviation/mean value of the quantity) that we calculated for these quantities in previous work [2]. Uncertainty on IPCC livestock $\mathrm{CH}_{4}$ emissions factors is given as $\pm 30 \%$ [4] , and is defined as representing \pm 1.96 times the standard deviation of the mean [34]. In order to be combined mathematically [34, 35 ] with our estimates of uncertainty on other $C$ fluxes, we used $15.3 \%$ (30\% divided by 1.96 ) as the uncertainty for all calculated $\mathrm{CH}_{4}$ quantities. 
Derivation of annual livestock $\mathrm{C}$ fluxes, including emissions of $\mathrm{CO}_{2}$ and $\mathrm{CH}_{4}$

We assumed a linear transition from IPCC 2006 emissions to revised emissions factors during the years 1990-2012:

$$
\mathrm{f}_{\text {yeari }}=\mathrm{f}_{\mathrm{IPCC}}+\left(\mathrm{f}_{\text {revised }}-\mathrm{f}_{\mathrm{IPCC}}\right) \cdot(\mathrm{Y} / 22)
$$

where $\mathrm{f}_{\text {yeari }}$ is the flux of $\mathrm{CH}_{4}$, feed, or other $\mathrm{C}$ containing quantity per animal in the year of interest; $\mathrm{f}_{\text {IPCC }}$ is the flux of $\mathrm{CH}_{4}$, feed, or other $\mathrm{C}$ quantity per animal given or calculated from data provided by 2006 IPCC guidelines [4]; $\mathrm{f}_{\text {revised }}$ is the revised flux of $\mathrm{CH}_{4}$, feed, or other $\mathrm{C}$ quantity per animal (resulting from this work); and $\mathrm{Y}$ is equal to 0 for years before 1990, to (year-1990) for 1990-2012; and to 22 for years after 2012 .

Livestock carbon dioxide $\left(\mathrm{CO}_{2}\right)$ emissions associated with respiration were estimated as the deficit between the $\mathrm{C}$ contained in annual livestock feed intake and the sum enteric fermentation $\mathrm{CH}_{4}$ emissions, production of milk or eggs, and manure production. Similarly, $\mathrm{CO}_{2}$ emissions associated with manure management were estimated as the difference between total manure $\mathrm{C}$ production and manure management $\mathrm{CH}_{4}$ emissions, assuming that all manure $\mathrm{C}$ is emitted as either $\mathrm{CH}_{4}$ or $\mathrm{CO}_{2}$ within one year of production.

\section{Livestock populations}

Annual national livestock populations of meat and milk-producing cattle, meat and milk-producing buffaloes, meat and egg-laying chickens, swine, sheep, turkeys, ducks, geese and guinea fowl, goats, horses, mules, asses, camels, and other camelids (i.e. llamas and alpacas) were compiled for years 1961-2013 from FAOSTAT [36]. Annual producing populations of egglaying chickens and milk-producing cattle and buffalo were subtracted from conspecific total populations to estimate populations raised for meat production. For all calculations made here, the dairy cattle livestock populations include only milk-producing mature dairy cows; calves, heifers, breeding steers, and any other dairy cattle 'replacements' are categorized with meat/ other cattle. For nine large countries (Argentina, Brazil, Canada, Chile, China, India, Kazakhstan, Mexico, and the Russian Federation), state- or province-level livestock population data were compiled for available years between 2000 and 2011 [37, 38], and used to improve the spatial distribution of inventory data. For the United States, livestock populations were refined to the county level using National Agricultural Statistical Service Census and Survey data [39]. Livestock in all other nations of the world are constrained at the national level only.

\section{Livestock $\mathrm{C}$ fluxes and $\mathrm{CH}_{4}$ emissions}

Accounting of livestock $\mathrm{C}$ fluxes was conducted as described in Wolf et al. [2]. Annual per-animal dry weight feed intake, dry weight manure production, manure $\mathrm{C}$ content, milk and egg production $\mathrm{C}$, and manure management and enteric fermentation $\mathrm{CH}_{4}$ emissions are from IPCC [4] or were estimated from existing literature. Livestock dry matter intakes were assumed to be $44 \% \mathrm{C}$ by weight. The difference between total livestock feed intake $\mathrm{C}$ and total $\mathrm{C}$ produced or emitted by live animals (i.e. the sum of $\mathrm{C}$ contained in manure, enteric fermentation $\mathrm{CH}_{4}$, and milk and eggs) approximates the amount of $\mathrm{C}$ respired in the form of $\mathrm{CO}_{2}$ over a given year, excluding $\mathrm{C}$ stored in livestock biomass. Although herd sizes do change over time, $C$ stored in livestock biomass is assumed constant in this effort. Similarly, the difference between total manure $\mathrm{C}$ content and manure management $\mathrm{CH}_{4}$ provides an estimate of $\mathrm{CO}_{2}$ released by livestock manure management, all of which is assumed to be emitted in the same year of manure production.

\section{Estimating livestock consumption of fodder and forage}

For purposes of tracking the use of all harvested crop C and estimating amounts of livestock forage, total livestock feed was disaggregated into fodder (i.e. biomass harvested by humans from croplands) and forage (i.e. biomass grazed or scavenged by livestock from noncropland sources) [2]. Fodder was further subdivided into (a) market feed items derived from primary harvests (e.g., grains, brans, crop by-product feeds), derived from FAO [36] (food balance: commodity balances, crops primary equivalent, feed category), (b) hay and fodder crops (e.g., harvested quantities of alfalfa, clovers, grasses, corn and sorghum silage) derived from FAO [36] (production: crops, crops primary list), including maize, alfalfa, and other grains, grasses, legumes, roots, and vegetables denoted as produced for forage and/or silage; category no longer available), and (c) crop residue feed, consisting of crop residue collected from the field for livestock feed, estimated from annual production of several utilized crops [2]. Annual national quantities of all market feed items and hay crops available were converted into units of $\mathrm{C}$ using fractional item-specific dry weights and $\mathrm{C}$ contents [2]. The crop residue feed quantities were estimated by applying crop-specific regional percentages of residues collected for feed [40] to the crop- and country-specific estimates of annual residue production. Total annual available fodder per nation is the sum of market feeds, hay and fodder crop production, and crop residues collected for feed. At the national level, annual available fodder was subtracted from total livestock feed intake requirement (calculated from national annual populations and 
per-animal feed intake values) to approximate national livestock forage intake, including grazing and scavenging. Because national quantities of market feeds and hay crops were not available for years after 2011 at the time of download, fodder and forage intake for 2012 and 2013 were estimated using average available quantities for each country over 2005-2011.

\section{Downscaling and spatial distribution of $\mathrm{C}$ fluxes}

Livestock $\mathrm{C}$ fluxes were downscaled and spatially distributed to $0.05 \times 0.05$ degree resolution using the MODIS Land Cover Type 5 data product for year 2005, following methods documented by West et al. [41] and Wolf et al. [2]. Downscaling started with the reconciling of land class areas between satellite-based land cover in 2005 and crop harvest area inventory data in each year from 2000 to 2011. Cropland area in 2005, based on MODIS, was compared to the sum of area inventoried for harvest per geopolitical region. The MODIS cropland areas were then adjusted to equal the sum of harvested areas for respective geopolitical regions and years. Cropland area was expanded or contracted as necessary, using a global kernel density representing the combined density of cropland and distance of each grid-cell to the nearest cropland region. Based on reconciled land cover information within each nation, state or province, or county, a separate amount of area was allocated to livestock. The livestock area requirement per nation, state/province, or county was derived from the livestock population therein, along with estimated area per animal required for each livestock type, for housed and free-ranging animals, and regional estimates of the proportion of animals that are free-ranging. Livestock were spatially distributed to grasslands, based on the livestock area requirement, per nation, state/province, or county. If there was insufficient grassland area, livestock were then distributed to shrubland areas. If grassland and shrubland areas together were smaller than the estimated required livestock area, the livestock area requirement was reduced to a smaller housed-animal area requirement value, thereby increasing livestock density. Respective carbon fluxes were subsequently applied to spatial livestock distributions.

\section{Results}

\section{Revised livestock emissions factors}

The revised emissions factors calculated here are greater than those given by IPCC 2006 for many, but not all, livestock types and regions (Table 3). The information we assembled to revise emissions factors highlights important recent changes in regional livestock systems. Mature dairy cattle body mass and milk productivity were greater in all global regions than IPCC 2006 default values, although the magnitude of increase varied (Table 1).
Revised enteric fermentation emissions factors for dairy cows range from $7 \%$ smaller (E. Europe and W. and Central Asia) to $125 \%$ larger (E. and S.E. Asia) than IPCC 2006 emissions factors (Table 3). Dairy manure management strategies changed along with increasing dairy cow body mass and productivity (Table 2 ). This resulted in more variable changes in manure management emissions factors among global regions than enteric fermentation emissions factors for dairy cows. Changes in dairy cow manure management emissions factors ranged from a $68 \%$ decrease in Oceania to a $158 \%$ increase in the US and Canada region (Table 3).

In contrast to the increases in mature dairy cow body mass, we found that body mass at time of slaughter for meat/other cattle decreased in several regions (Table 2). The mature weights of producing dairy cows are determined by breed/genetics and nutritional status of the animals. While this is also true for meat/other cattle, slaughter weights for meat animals are also determined by management decisions, and as such may vary with changing economic or environmental factors (e.g. weather extremes, feed costs, or meat prices and demand). For meat cattle in many regions, external factors also influence the weight at which grazing animals are placed on feedlots to be grain-finished-with very large differences in manure management $\mathrm{CH}_{4}$ emissions between these situations (Table 2). Changes in emissions factors for enteric fermentation in meat/other catthe ranged from an $18 \%$ decrease (W. Europe) to a $54 \%$ increase (E. and S.E. Asia). Manure management $\mathrm{CH}_{4}$ emissions factors for meat/other cattle are overall much smaller than those for dairy cows, and the IPCC 2006 default factors are rounded to the nearest integer value (e.g. "1"). Therefore, some of the changes reported here result merely from inclusion of additional significant digits. Given the large global populations of meat/other cattle, these small changes are nevertheless important. Revision of manure management emissions factors for meat/other cattle resulted in variable changes among regions, ranging from a $60 \%$ decrease (E. and S.E. Asia) to a 140\% increase (US and Canada).

Changes in swine manure management emissions factors, relative to IPCC 2006 reported values, range from $-4 \%$ (W. Europe) to $+1800 \%$ in Latin America. The latter large increase is due to modernization of swine production in that region, including use of improved breeds with larger potential body mass, changing animal diet, and in particular a shift from dry manure management systems to anaerobic lagoons.

\section{Revised global livestock C fluxes}

Fluctuations in annual livestock populations [FAO, 36] play a large role in the magnitude of $\mathrm{C}$ fluxes associated 


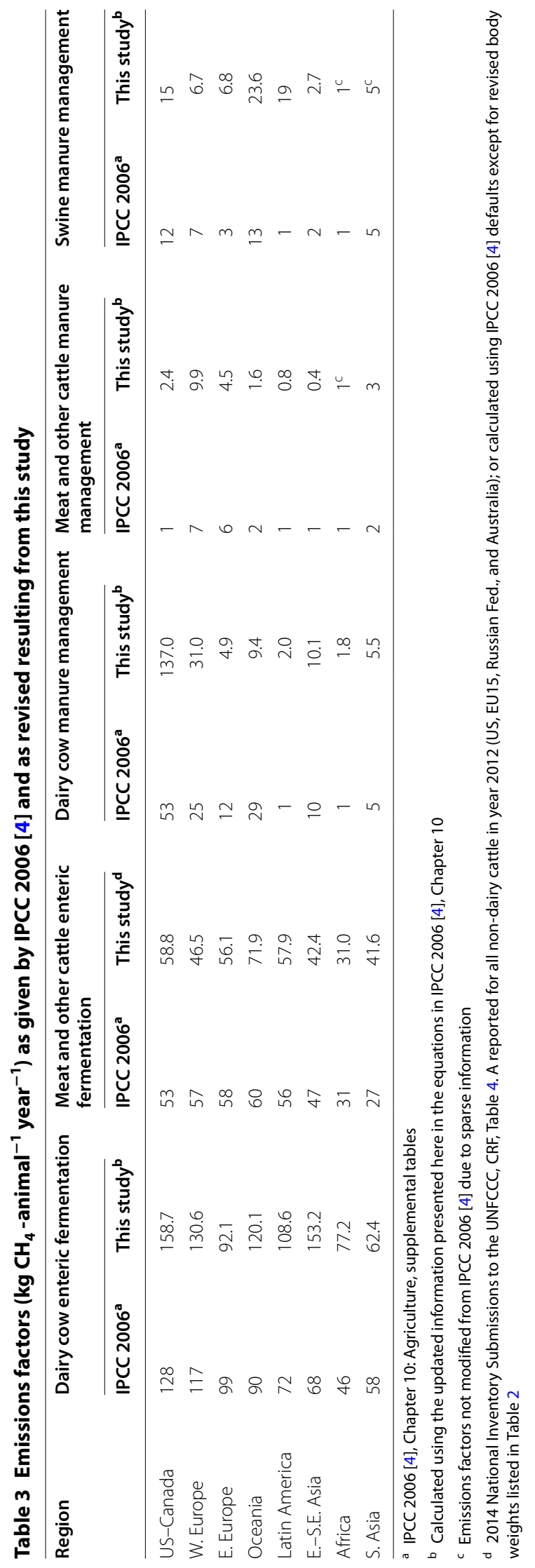


with livestock, including $\mathrm{CH}_{4}$ emissions. Global populations of most livestock species did not change greatly over the years between 1990 and 2013, except for goats and chickens (Fig. 1). However, when separated by region, changes in the distribution of global cattle and swine populations are apparent (Fig. 2). For dairy cows, meat/other cattle, and swine, populations in W. Europe and US and Canada regions remained steady or declined slightly over the years in this study. In contrast, meat/ other cattle populations increased dramatically in Latin America during the early 2000s, and the already large swine population in E. and S.E. Asia has continued to increase in recent decades.

Total livestock $\mathrm{CH}_{4}$ emissions account for ca. 3\% of total livestock C fluxes (Fig. 3; Table 4). Nevertheless, estimating livestock $\mathrm{CH}_{4}$ emissions with our revised

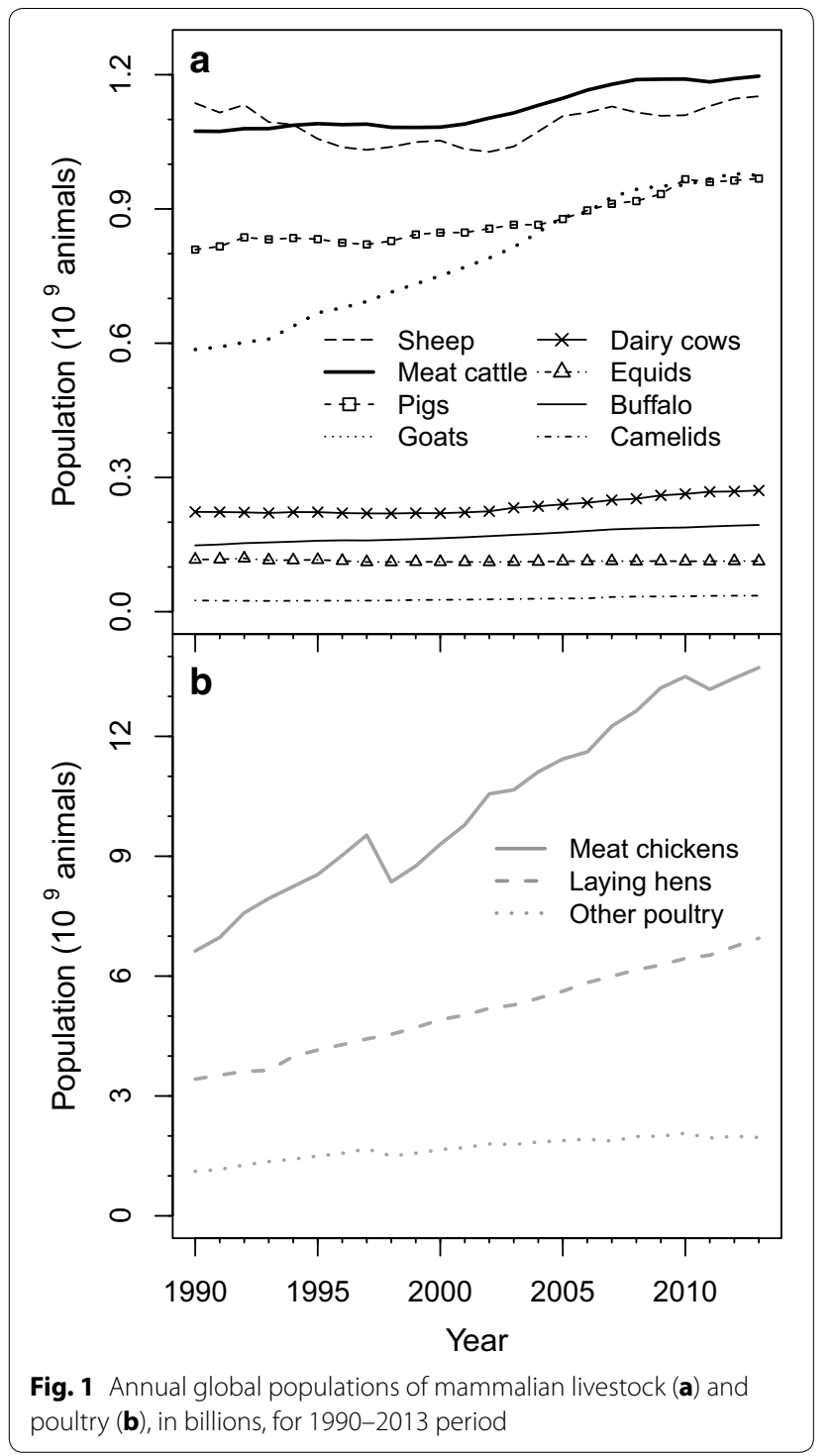

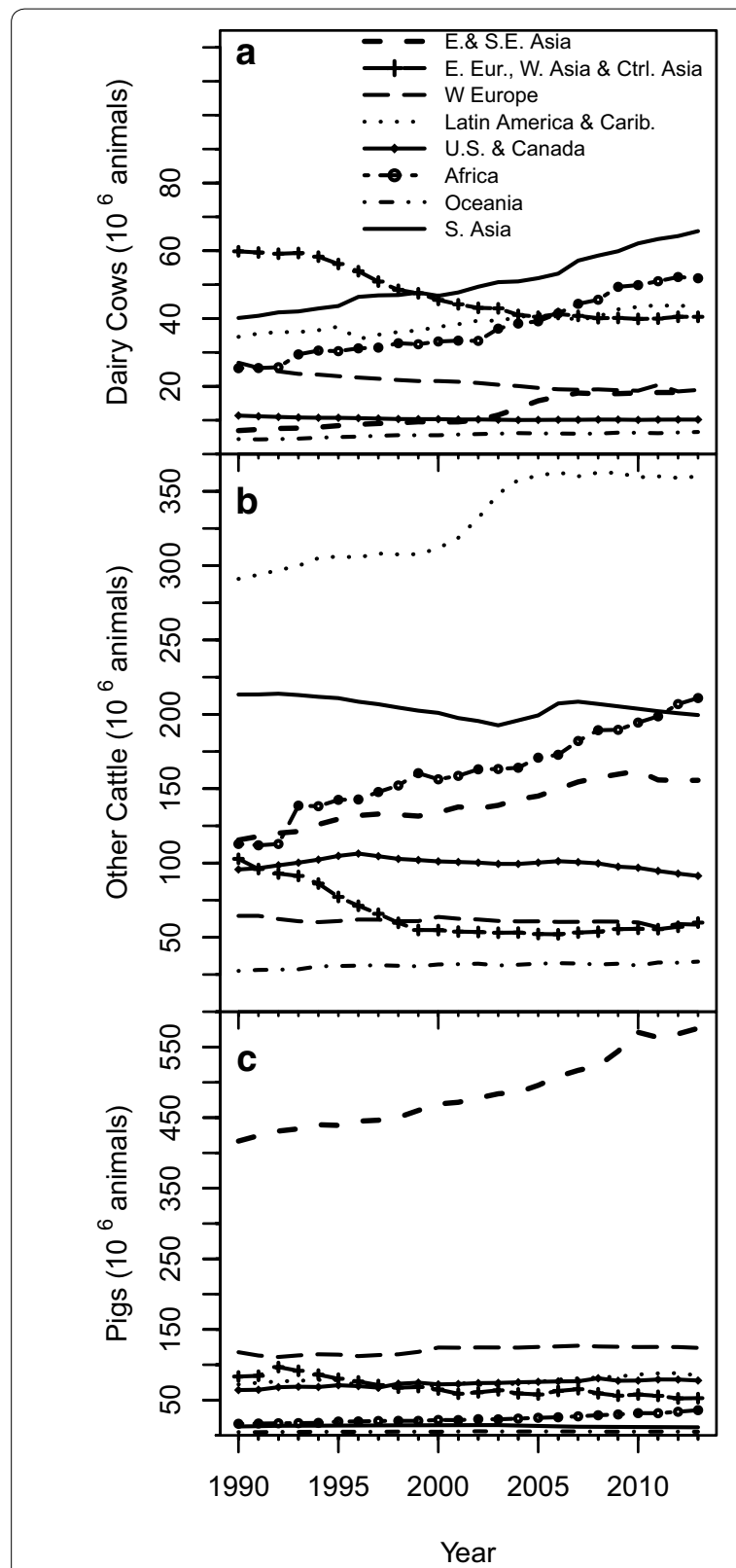

Fig. 2 Annual regional populations of dairy cattle, meat/other cattle, and swine

emissions factors results in discernably larger emissions relative to calculations made using IPCC 2006 emissions factors. Revised global total $\mathrm{CH}_{4} \mathrm{C}$ emission quantities for 2011 are $89.4 \pm 13.7 \mathrm{Tg} \mathrm{C}\left(119.1 \pm 18.2 \mathrm{Tg} \mathrm{CH}_{4}\right)$, an increase of $11 \%$ over estimates made using IPCC 2006 emissions factors. This change encompasses an $8.4 \%$ increase in enteric fermentation $\mathrm{CH}_{4} \mathrm{C}$ and a $36.7 \%$ increase in manure management $\mathrm{CH}_{4} \mathrm{C}$ (Fig. 4a). In certain regions, these changes are more pronounced, such as in the US and Canada (Fig. 4b), where 2011 total 

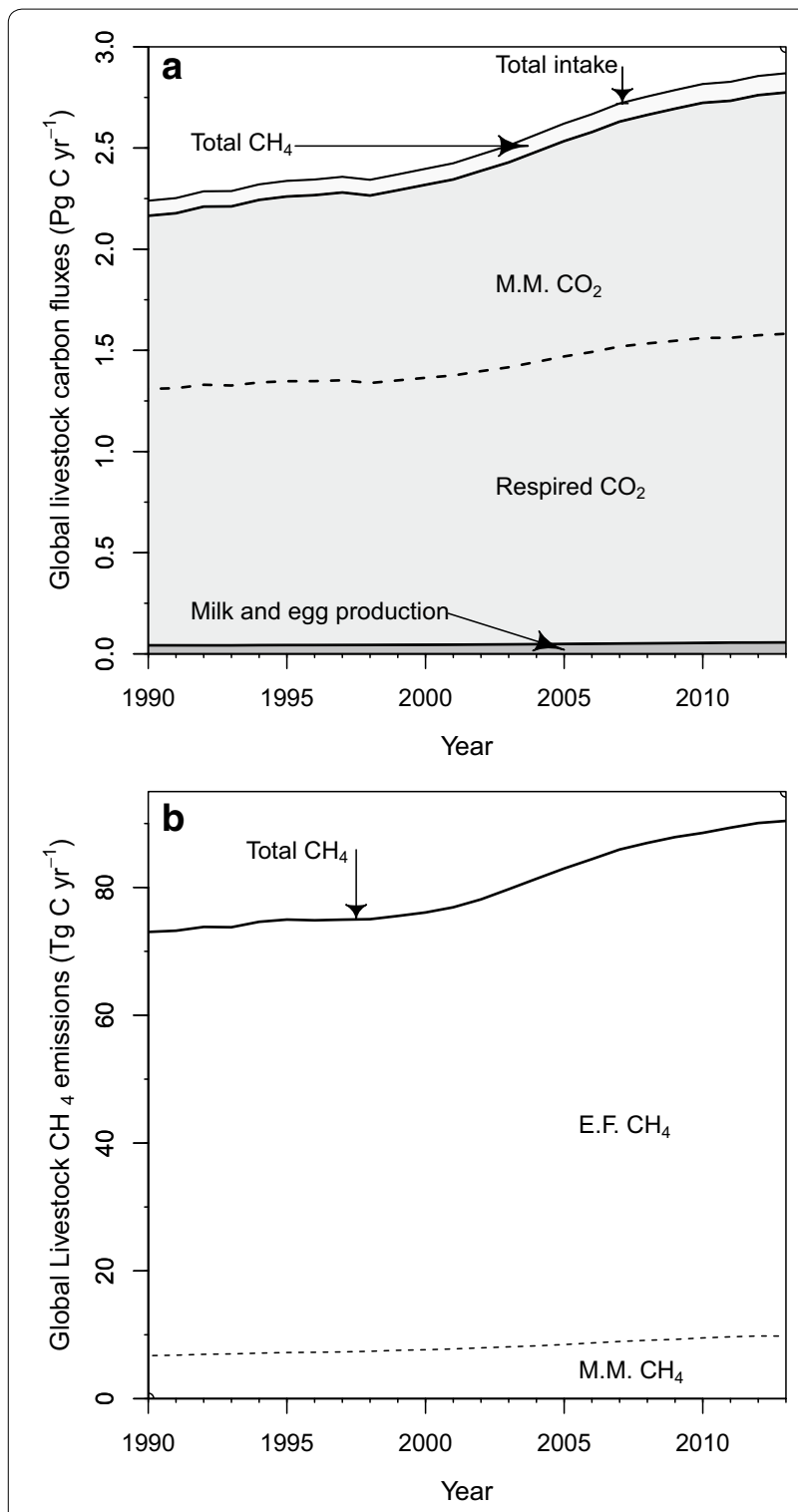

Fig. 3 Revised annual global livestock carbon fluxes, 1990-2013: carbon contained in all fluxes associated with livestock (a), and carbon contained in methane emissions associated with manure management (M.M.) and enteric fermentation (E.F.). Note different units

livestock $\mathrm{CH}_{4}$ emissions were $24.2 \%$ greater than when calculated with IPCC 2006 emissions factors, including a $12.3 \%$ increase in enteric fermentation $\mathrm{CH}_{4} \mathrm{C}$ and a $71.8 \%$ increase in manure management $\mathrm{CH}_{4} \mathrm{C}$ (Fig. 4b).

Over the 1990-2013 period, total livestock $\mathrm{CH}_{4} \mathrm{C}$ emissions exhibit contrasting dynamics among global regions (Fig. 5a) due to trends in livestock populations (Fig. 2) as well as to revision of emission factors (Table 3). The changes in total livestock emissions relative to IPCC 2006 calculations vary by region (Fig. 5b). The largest changes are seen in the US and Canada region, despite declines in dairy $(-7.7 \%)$ and meat/other cattle $(-5.8 \%)$ populations there (Figs. 2, 5b).

Livestock $\mathrm{C}$ fluxes, including solids (i.e. feed intake and manure production) and gases (i.e. respiration and manure management $\mathrm{CO}_{2} \mathrm{C}$, and enteric fermentation and manure management $\mathrm{CH}_{4} \mathrm{C}$ ) are downscaled and mapped at $0.05 \times 0.05^{\circ}$ resolution, in both $\mathrm{g} \mathrm{C}$ per $\mathrm{m}^{2}$ and $\mathrm{Mg} \mathrm{C}$ per $0.05^{\circ}$ gridcell formats for years 2000-2013. The maps show the interplay between regional livestock characteristics and emissions factors, national, state, or county level cohorts of various livestock species and types, and local densities of livestock. For livestock $\mathrm{CH}_{4}$ C fluxes in 2011 (Fig. 6), the percent change from calculations made using IPCC 2006 emissions factors are also downscaled and mapped (Fig. 7).

\section{Revised livestock forage intake and global livestock C budget}

We show the revised global livestock $C$ budget for 2011 in Fig. 8, using boxes with areas proportional to the magnitudes of the $C$ flux represented. Our revised data are available through 2013, but because livestock fodder items were not available beyond the year 2011 at the time of data download [36], we estimated 2012 and 2013 fodder quantities based on 2005-2011 average availability. Crop NPP, primary (main crop) harvest $\mathrm{C}$, and residue collected for feed were calculated as in Wolf et al. [2]; reported meat production is converted to $\mathrm{Tg} C$ from FAO reports [36] of total global meat production in 2011 (292 $\mathrm{Tg}$ of meat entering food supply) multiplied by conversion factors to estimate $\mathrm{C}$ content [2]. Estimated milk and egg production are the result of our calculations, based on estimated per-animal production by region. Our global value of $55.7 \mathrm{Tg} \mathrm{C}$ is similar to the value of $55.2 \mathrm{Tg} \mathrm{C}$ obtained by multiplying FAO reported global production [36] (743 $\mathrm{Tg}$ of milk, $71 \mathrm{Tg}$ of eggs), and conversion factors for milk and egg $\mathrm{C}$ content in 2011 [2]. In comparison to primary crop harvest, crop residue harvest, and the quantity of livestock-based food produced, the magnitude of livestock fodder and forage consumption is apparent. Emissions of $\mathrm{CO}_{2}$ associated with livestock respiration and manure management are also shown, which are calculated by subtraction of all other fluxes from total intake or total manure production at the per-animal level, assuming static standing live populations with no net change in biomass across years.

Note that the 'market feed' category includes primary crop products as well as crop by-products that are unsuited or undesirable for human consumption, such as distillers grains (a by-product of bioethanol production) and various oil-crop extraction by-products (e.g. oil seed meal or cake). The $\mathrm{C}$ contained in and used for production of biofuels is included in the harvest/other uses box, but 
Table 4 Livestock C fluxes by region for year 2011

\begin{tabular}{|c|c|c|c|c|c|c|c|c|c|}
\hline \multirow{2}{*}{$\begin{array}{l}2011 \\
\text { livestock C } \\
\text { fluxes } \pm 1 \mathrm{SE}\end{array}$} & \multicolumn{9}{|l|}{ Region } \\
\hline & Africa & E.-S.E. Asia & $\begin{array}{l}\text { E. Europe, } \\
\text { W. Asia, } \\
\text { and Central } \\
\text { Asia }\end{array}$ & $\begin{array}{l}\text { Latin } \\
\text { America }\end{array}$ & Oceania & S. Asia & $\begin{array}{l}\text { US and Can- } \\
\text { ada }\end{array}$ & W. Europe & Globe \\
\hline Intake C (Tg C) & $415 \pm 52.2$ & $610.7 \pm 67.8$ & $261 \pm 31.8$ & $559.5 \pm 80.4$ & $76.6 \pm 10.5$ & $451.2 \pm 66.7$ & $256.1 \pm 34$ & $195.7 \pm 26.3$ & $2825.7 \pm 369.8$ \\
\hline $\begin{array}{l}\text { Manure } \\
\text { production } \\
\mathrm{C}(\mathrm{Tg} C)\end{array}$ & $176.4 \pm 30.8$ & $219.8 \pm 35.4$ & $111.4 \pm 19.2$ & $259.1 \pm 49.5$ & $34.7 \pm 6.2$ & $197.4 \pm 37.8$ & $99.8 \pm 18.4$ & $82.5 \pm 15$ & $1181.1 \pm 212.4$ \\
\hline $\begin{array}{l}\text { Enteric } \\
\text { Fermenta- } \\
\text { tion } \mathrm{CH}_{4} \mathrm{C} \\
(\mathrm{Tg} \mathrm{C})\end{array}$ & $12.69 \pm 1.94$ & $10.5 \pm 1.61$ & $6.16 \pm 0.94$ & $20.26 \pm 3.1$ & $2.97 \pm 0.45$ & $16.89 \pm 2.58$ & $5.64 \pm 0.86$ & $4.56 \pm 0.7$ & $79.67 \pm 12.19$ \\
\hline $\begin{array}{l}\text { Manure } \\
\text { Manage- } \\
\text { ment } \mathrm{CH}_{4} \mathrm{C} \\
(\mathrm{TgC} \text { C) }\end{array}$ & $0.45 \pm 0.07$ & $1.53 \pm 0.23$ & $0.73 \pm 0.11$ & $1.63 \pm 0.25$ & $0.21 \pm 0.03$ & $1.39 \pm 0.21$ & $2.16 \pm 0.33$ & $1.58 \pm 0.24$ & $9.68 \pm 1.48$ \\
\hline Total $\mathrm{CH}_{4} \mathrm{C}$ & $13.14 \pm 2.01$ & $12.03 \pm 1.84$ & $6.89 \pm 1.05$ & $21.89 \pm 3.35$ & $3.18 \pm 0.49$ & $18.29 \pm 2.8$ & $7.79 \pm 1.19$ & $6.14 \pm 0.94$ & $89.35 \pm 13.67$ \\
\hline $\begin{array}{l}\text { Milk and egg } \\
\text { production } \\
\mathrm{C}(\operatorname{Tg} \mathrm{C})\end{array}$ & $3.41 \pm 0.84$ & $8.34 \pm 1.95$ & $9.52 \pm 2.35$ & $4.75 \pm 1.15$ & $2.32 \pm 0.58$ & $9.9 \pm 2.46$ & $7.27 \pm 1.79$ & $10.21 \pm 2.53$ & $55.73 \pm 13.65$ \\
\hline $\begin{array}{l}\text { Respiration } \\
\qquad \mathrm{CO}_{2} \mathrm{C}(\mathrm{Tg} \mathrm{C})\end{array}$ & $222.5 \pm 87.7$ & $372 \pm 108.3$ & $133.9 \pm 55.4$ & $275.4 \pm 137.1$ & $36.6 \pm 18.4$ & $227 \pm 112$ & $143.3 \pm 56.3$ & $98.5 \pm 45.4$ & $1509.2 \pm 620.6$ \\
\hline $\begin{array}{l}\text { Manure } \\
\text { manage- } \\
\text { ment } \mathrm{CO}_{2} \mathrm{C} \\
(\mathrm{TgC})\end{array}$ & $176 \pm 31$ & $218.3 \pm 35.8$ & $110.7 \pm 19.5$ & $257.4 \pm 50$ & $34.5 \pm 6.3$ & $196 \pm 38.2$ & $97.7 \pm 19$ & $80.9 \pm 15.5$ & $1171.4 \pm 215.3$ \\
\hline $\begin{array}{l}\text { Available fod- } \\
\text { der (Tg C) }\end{array}$ & 83 & 260.5 & 212.7 & 157.3 & 8.6 & 231.6 & 136.6 & 156.9 & 1247.2 \\
\hline $\begin{array}{l}\text { Unused/waste } \\
\text { fodder }^{\text {a }}\end{array}$ & 4.9 & 8.6 & 38.4 & 0 & 0 & 0.5 & 0 & 19.4 & 71.8 \\
\hline $\begin{array}{l}\text { Fodder intake } \\
\quad(\operatorname{Tg} C)\end{array}$ & 78.1 & 251.9 & 174.2 & 157.3 & 8.6 & 231.1 & 136.6 & 137.6 & 1175.4 \\
\hline $\begin{array}{l}\text { Forage intake } \\
\quad(\operatorname{Tg} C)\end{array}$ & 336.9 & 358.7 & 86.8 & 402.1 & 68 & 220.1 & 119.5 & 58.2 & 1650.3 \\
\hline $\begin{array}{l}\% \text { of intake } \\
\text { from forage }\end{array}$ & 81.2 & 58.7 & 33.2 & 71.9 & 88.8 & 48.8 & 46.7 & 29.7 & 58.4 \\
\hline
\end{tabular}

C contained in biofuel by-products sold and consumed as feed are pushed back into the primary harvest for feed/ market feeds box; this results in a smaller total amount of $\mathrm{C}$ devoted to biofuels than in calculations that do not account for use of by-products in livestock feeds [2].

For most livestock types and regions, default livestock body weights and total feed requirements increased in our revision (Tables 1, 2). Reported amounts of annual available fodder, however, did not change [36]. In our accounting, the gap between total feed requirements and available fodder in each nation, if any, is filled by forage intake (i.e. grazing). Therefore, our revision of total livestock feed requirements also necessitated revision of livestock forage intake and the percentage of total livestock $C$ intake supplied by forage. The revised percent of global livestock intake supplied by forage was $58.4 \%$ in 2011, reflecting $1.65 \mathrm{Pg} C$ of forage intake from global rangelands (Table 4; Fig. 9b). These percentages are similar to estimates reported by other researchers; Bouwman et al. [42] estimated $59.2 \%$ of total livestock intake from forage in 1990 (our value is $56.6 \%$ for that year), and Krausman et al. [40] estimated $54.5 \%$ in 2000 (our value is $58.6 \%$ ). When feed intake requirements were calculated using IPCC 2006 or IPCC 1996 [2, 3] livestock total intake values, the estimates for 2011 were 55.2 and $52.4 \%$, respectively.

Although the percentage of forage intake increased based on our revision, the global average percentage did not change greatly over the 1990-2011 time period, ranging between 56.6 and $60.7 \%$ (Fig. 9b). This suggests that, at the global level, amounts of forage and fodder intake 


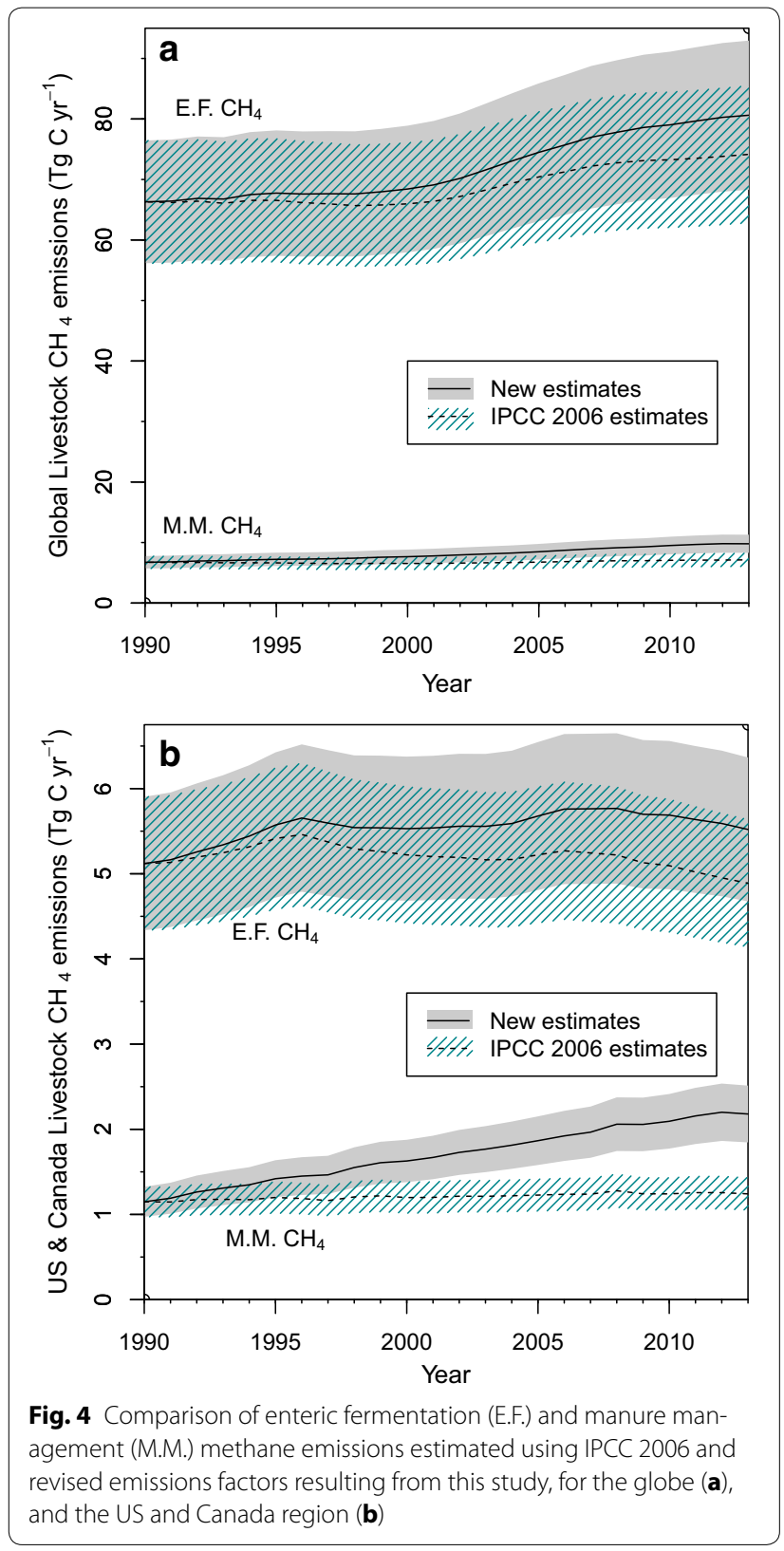

$\mathrm{C}$ have increased apace over this time period to meet increasing total livestock intake requirements. This is also true in most regions during this time period, except for E. Europe and West and Central Asia after the breakup of the Soviet Union. However, in the US and Canada, the percentage of intake from forage increased sharply in 1995 and again after 2009, with the 2011 value (45.1\%) doubled from 2005 (22.4\%). Additional data from USDA (annual grain quantities fed, hay harvests, and by-product feed quantities excluding distiller's grains) [43] and from the Renewable Fuels Association (annual quantities of distiller's grains by-products from bioethanol production

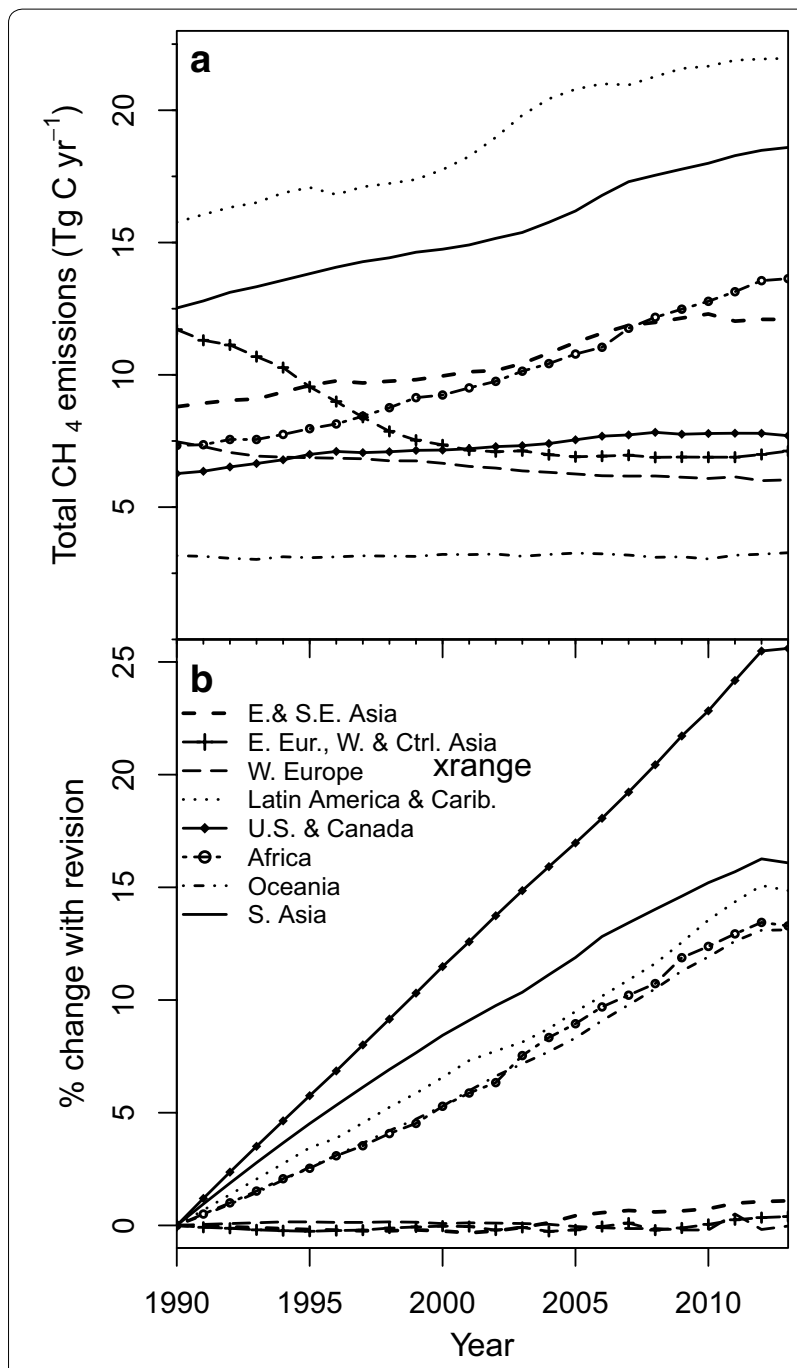

Fig. 5 Revised total livestock methane emissions by region (a) and percent change in annual emissions relative to calculations made based on IPCC 2006 emissions factors

in the US, decreased by the estimated one-third that is exported annually) [44] were converted to units of C [2] to provide approximate annual amounts of available fodder in the US (Fig. 10). These data support the observed increases in percent livestock intake from forage in those years. The spike in and after 1995 can be attributed to drought in the Midwest US and other factors [45]. Uncertain harvests in the US and in E. Europe, along with the increasing use of corn for bioethanol production, may be the causes of the sharp increase after 2009 [46]. Corn prices, which averaged $\$ 2.75$ per bushel in the 2000s, jumped to an average of $\$ 6.10$ in $2010-2013$ [43]. The jump in corn prices could have driven farmers to delay moving cattle from pasture to feedlots, without deterring the subsidized and mandated production of bioethanol 

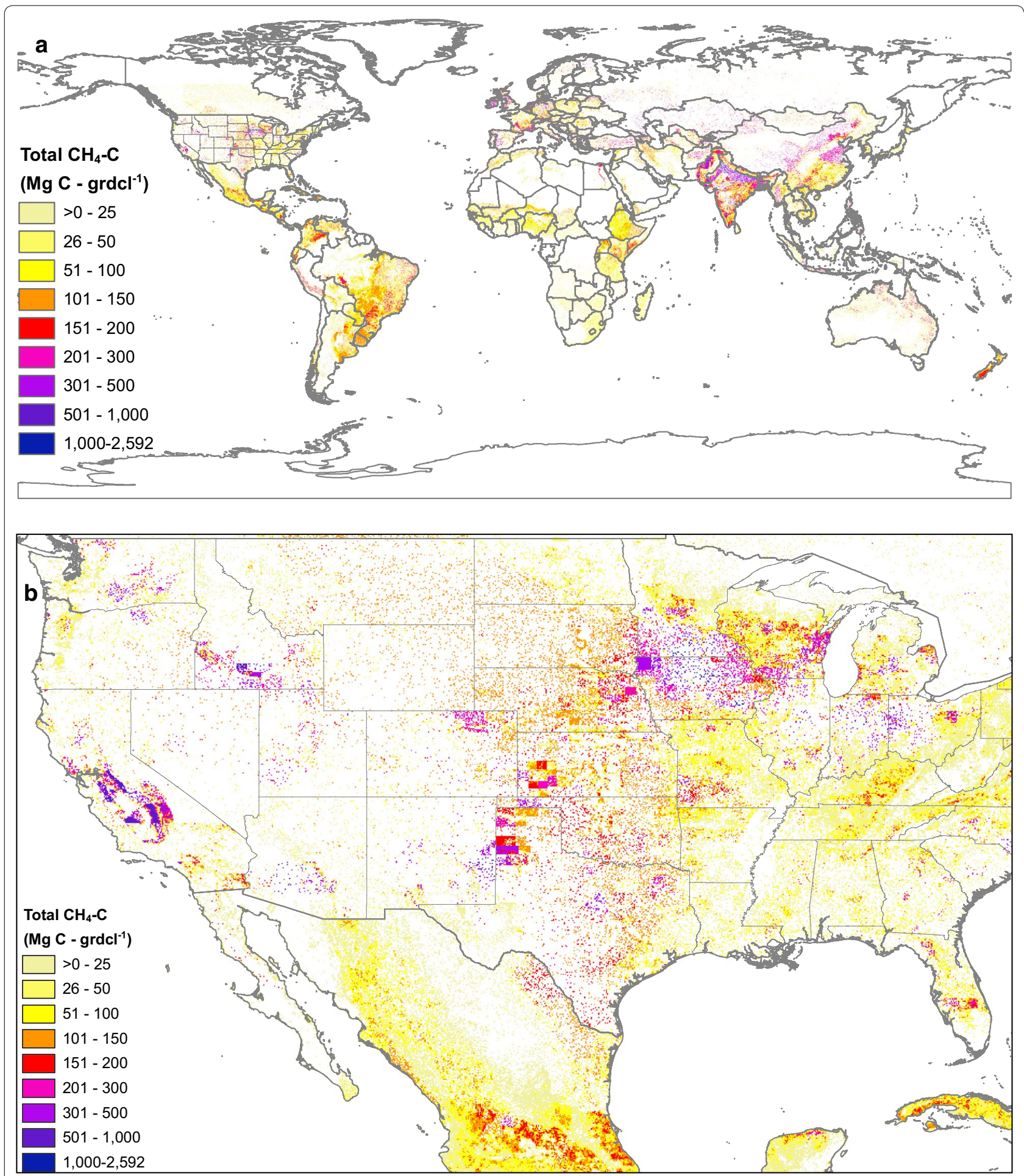

Fig. 6 Total livestock methane emissions in 2011, downscaled to $0.05 \times 0.05^{\circ}$ resolution, for the globe (a) and detail for the western US (b)

in the US. In addition to the impacts of corn prices, the by-products of corn bioethanol production (i.e. distiller's grains) are used as a high energy, high protein livestock feed supplement, which affects other components of livestock feed and forage intake [47] and potentially $\mathrm{CH}_{4}$ emissions from livestock consuming them [48]. 

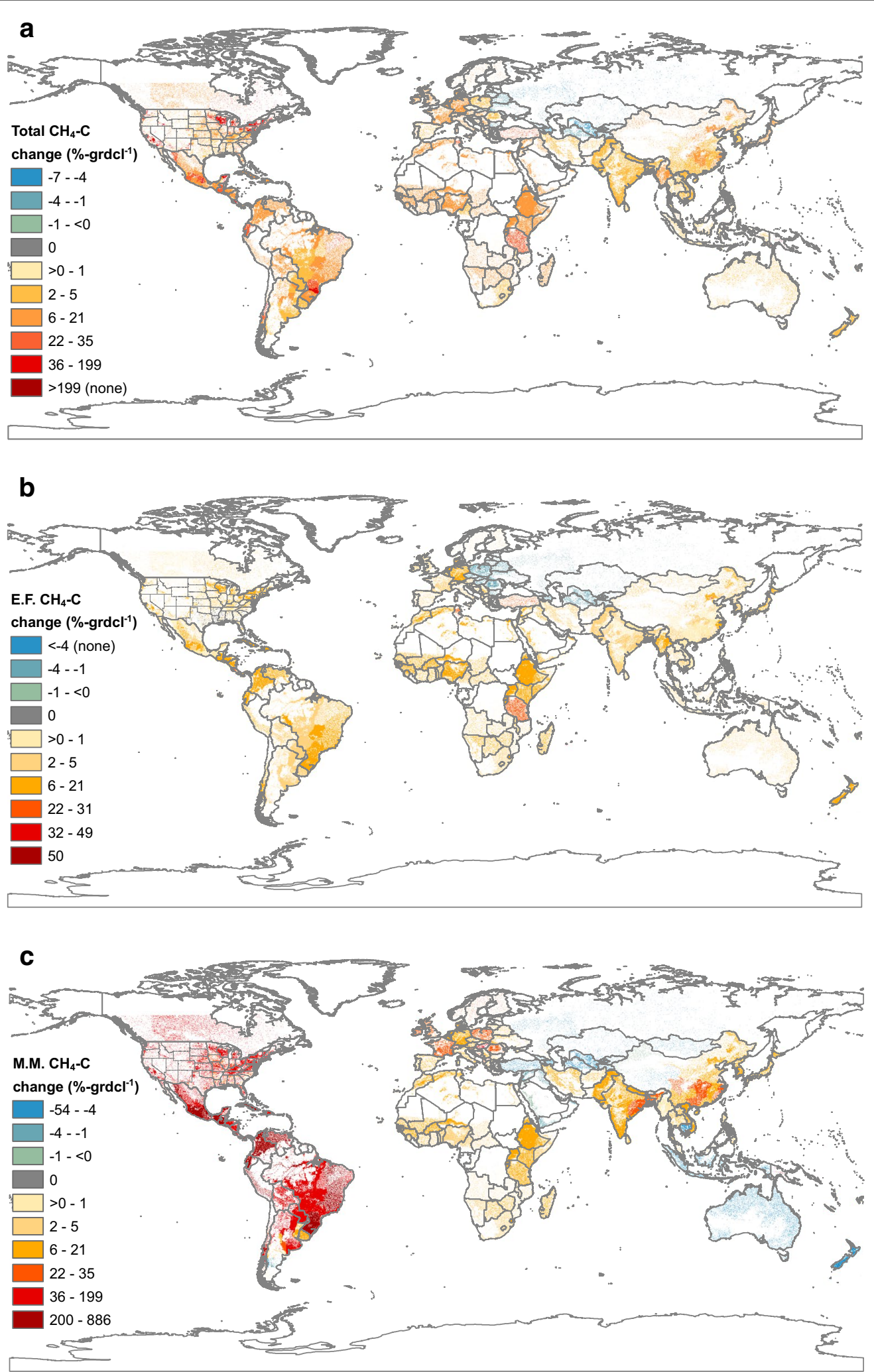

Fig. 7 Percent change in global livestock methane emissions with revision, downscaled to $0.05 \times 0.05^{\circ}$ resolution, for the total (a), enteric fermentation (E.F.) (b), and manure management methane (M.M.) emissions (c), in 2011 


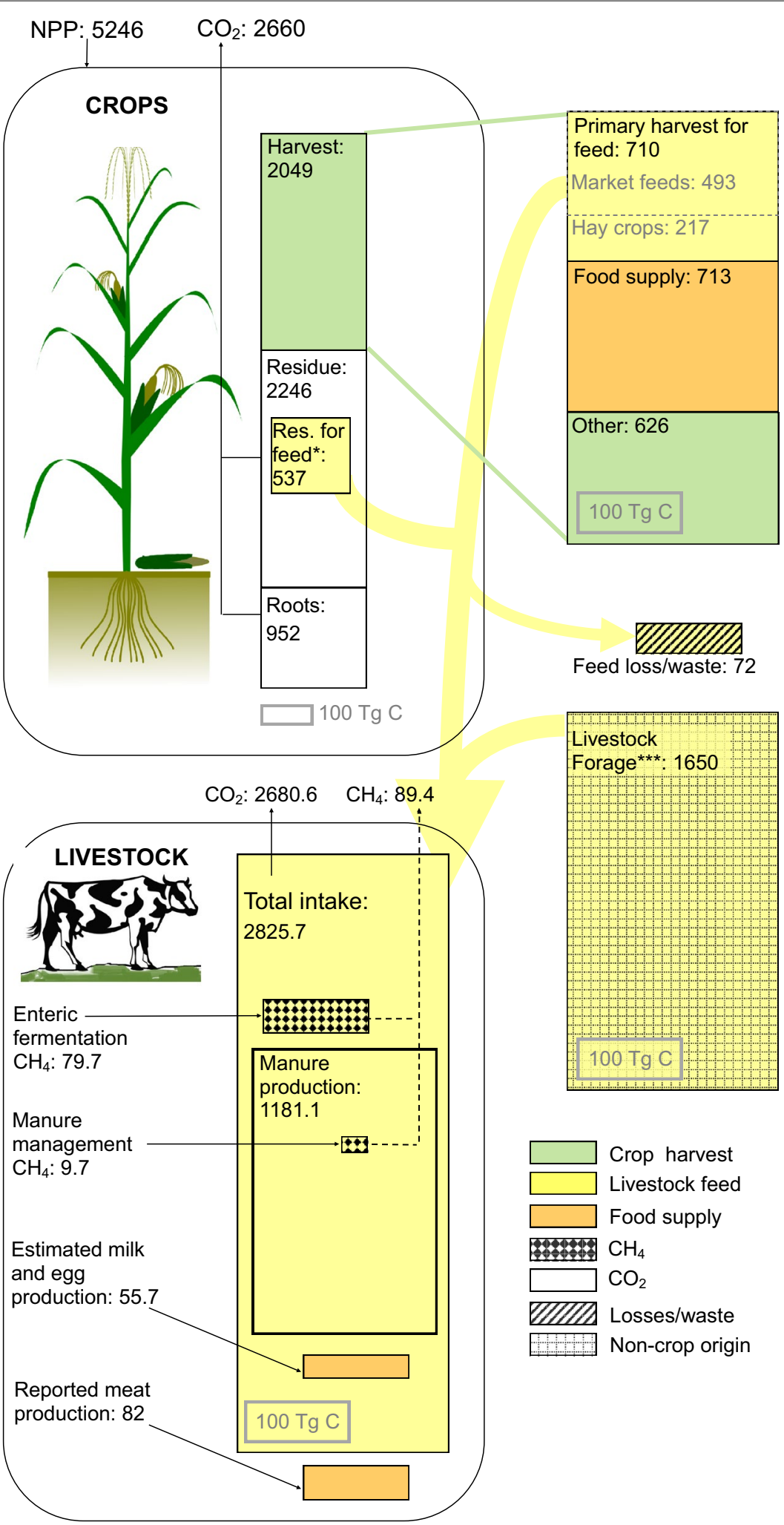

Fig. 8 Revised livestock $C$ budget for 2011. All non-harvested crop biomass $C$, and all manure $\mathrm{C}$ not emitted as $\mathrm{CH}_{4}$, are assumed to be decomposed and respired as $\mathrm{CO}_{2}$ by decomposing organisms within the same year as production 


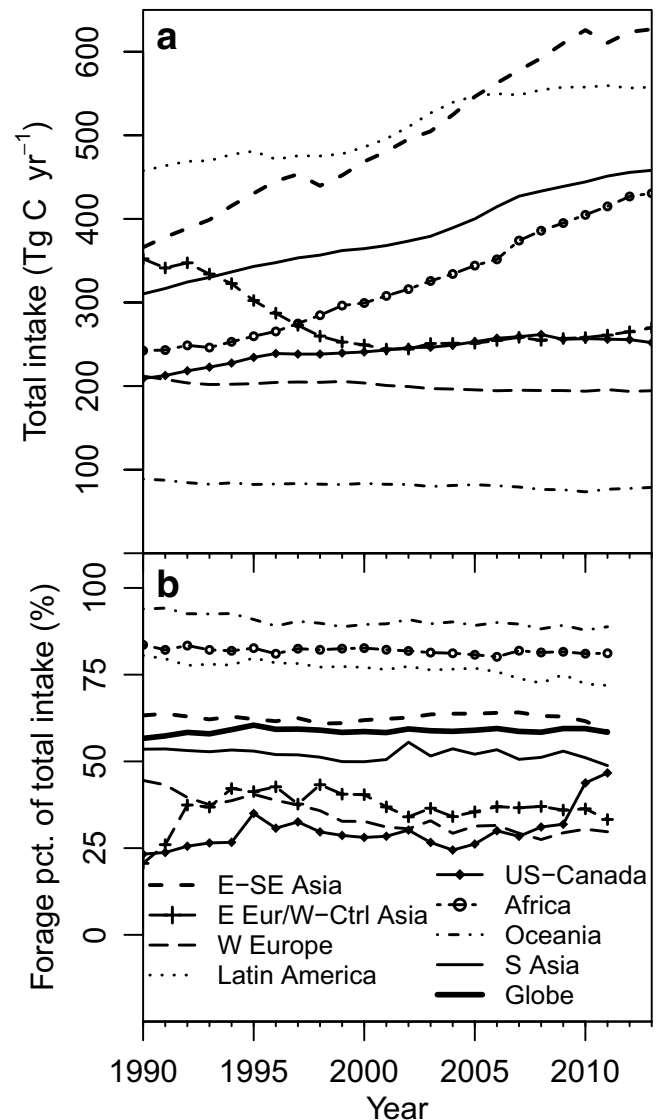

Fig. 9 Revised total livestock feed intake carbon (a) and percent supplied by forage (b) by region

\section{Discussion}

\section{Evaluation of revised livestock $\mathrm{CH} 4$ emissions estimates}

Compared to other bottom-up estimates for recent years (Table 5), our revised emissions factors yield annual $\mathrm{CH}_{4}$ $\mathrm{C}$ emission estimates that are: $11 \%$ larger than global estimates made using IPCC 2006 emissions factors; 15\% larger than EPA global estimates but similar or slightly smaller than EPA US estimates; and 4\% larger than EDGAR global estimates, 3\% larger than EDGAR US estimates, but $54 \%$ larger than EDGAR estimates for the state of California. Our global estimates are slightly larger than those published for the 2000s by Tian et al. [49] based on a suite of bottom-up estimates, but have larger uncertainties. EDGAR uses IPCC 2006 Tier 2 calculations but modifies cattle emissions factors based on body weight or milk productivity; such modifications would not capture the effects of recent changes in manure management systems and other factors. EPA, in contrast, uses models with annually modified inputs for the US [50], but uses 2006 IPCC coefficients for its global estimates [16]. Our US emissions estimates are not significantly different

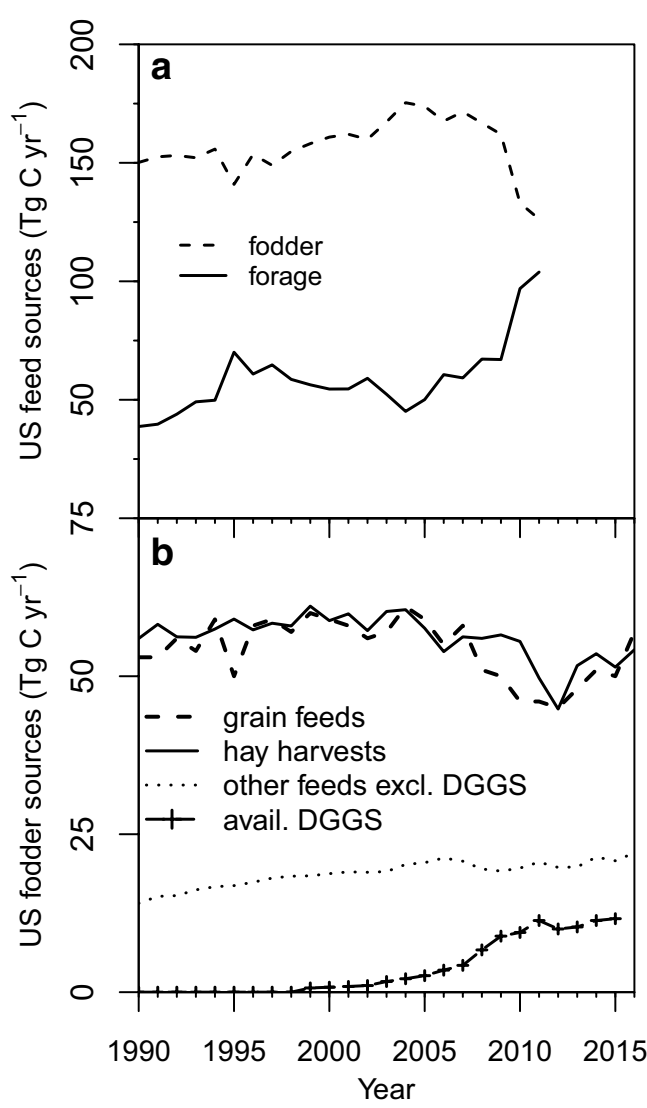

Fig. 10 Detail of US livestock intake of fodder and forage (a) and US fodder sources $(\mathbf{b})$

from those made by EPA. This is not unexpected, as we use similar estimates for enteric fermentation emissions in US meat/other cattle, and rely on information from EPA to derive the new emissions factors for other livestock categories.

Our estimate of global livestock $\mathrm{CH}_{4} \mathrm{C}$ emissions is similar to top-down estimates made using atmospheric inversion methods [20] (Table 5). Our estimates for the US, however, are smaller than recent top-down estimates by $21-51 \%$ [20], $46 \%$ [23], or $30 \%$ [21]. For the state of California only, our total-livestock estimate is $17 \%$ smaller than top-down [22] for 2010; for 2013, our estimate for non-dairy livestock was smaller but comparable, while our dairy cattle estimate was $37-64 \%$ smaller, than top-down [51] (Table 5). The differences over the entire US may be due in part to the difficulty in separating livestock $\mathrm{CH}_{4}$ emissions from other sources for the entire country in top-down studies [20]. US emissions could indeed be larger than our estimates, as suggested by these top-down studies; however, further investigation of this possibility will require more quantitative research on recent per animal emissions, particularly from 
Table 5 Comparison of livestock $\mathrm{CH}_{4} \mathrm{C}$ emissions reported in literature to revised values obtained in this study

\begin{tabular}{|c|c|c|c|c|c|c|}
\hline Area & Years & Methane quantity & $\begin{array}{l}\text { Source/emissions factors } \\
\text { used }\end{array}$ & Method & Value $\left(\operatorname{Tg} C\right.$ year $\left.^{-1}\right)$ & $\begin{array}{l}\text { Revised value } \\
\left(\operatorname{TgC~} \text { year }^{-1}\right)\end{array}$ \\
\hline \multirow[t]{6}{*}{ Globe } & 2013 & Total Ivstk. $\mathrm{CH}_{4} \mathrm{C}$ & IPCC $2006^{a}$ & Bottom-up & $81.3 \pm 12.4$ & $90.4 \pm 13.8$ \\
\hline & & & IPCC 2006 [36] & & 81.0 & \\
\hline & & E.F. $\mathrm{CH}_{4} \mathrm{C}$ & IPCC 2006 & Bottom-up & $74.2 \pm 11.4$ & $80.6 \pm 12.3$ \\
\hline & & & IPCC 2006 [36] & & 73.8 & \\
\hline & & M.M. $\mathrm{CH}_{4} \mathrm{C}$ & IPCC 2006 & Bottom-up & $7.14 \pm 1.09$ & $9.79 \pm 1.5$ \\
\hline & & & IPCC 2006 [36] & & 7.24 & \\
\hline \multirow[t]{6}{*}{ Globe } & 2012 & Total Ivstk. $\mathrm{CH}_{4} \mathrm{C}$ & IPCC 2006 & Bottom-up & $80.9 \pm 12.4$ & $90.08 \pm 13.78$ \\
\hline & & & IPCC 2006 [36] & & 80.6 & \\
\hline & & E.F. $\mathrm{CH}_{4} \mathrm{C}$ & IPCC 2006 & Bottom-up & $73.8 \pm 11.3$ & $80.3 \pm 12.3$ \\
\hline & & & IPCC 2006 [36] & & 73.4 & \\
\hline & & M.M. $\mathrm{CH}_{4} \mathrm{C}$ & IPCC $2006^{\mathrm{a}}$ & Bottom-up & $7.10 \pm 1.1$ & $9.81 \pm 1.5$ \\
\hline & & & IPCC 2006 [36] & & 7.19 & \\
\hline \multirow[t]{2}{*}{ Globe } & 2009-2011 & Total Ivstk. $\mathrm{CH}_{4} \mathrm{C}$ & {$[20]$} & Top-down & 88.94 & $87.88 \pm 13.44(2009)$ \\
\hline & & & & & & $89.35 \pm 13.67(2011)$ \\
\hline \multirow[t]{2}{*}{ Globe } & 2010 & E.F. $\mathrm{CH}_{4} \mathrm{C}$ & {$[88]$} & Bottom-up & 69.0 & $79.0 \pm 12.1$ \\
\hline & & M.M. $\mathrm{CH}_{4} \mathrm{C}$ & & & 8.19 & $9.51 \pm 1.5$ \\
\hline \multirow[t]{2}{*}{ Globe } & 2000s (average) & E.F. $\mathrm{CH}_{4} \mathrm{C}$ & {$[49]$} & Bottom-up & $70.0 \pm 3.3$ & $72.0 \pm 11.0$ \\
\hline & & M.M. $\mathrm{CH}_{4} \mathrm{C}$ & & & $8.0 \pm 0.3$ & $8.4 \pm 1.29$ \\
\hline \multirow[t]{6}{*}{ US } & 2012 & E.F. $\mathrm{CH}_{4} \mathrm{C}$ & IPCC $2006^{\mathrm{a}}$ & Bottom-up & $4.38 \pm 0.67$ & $4.95 \pm 0.76$ \\
\hline & & & IPCC 2006 [36] & & 4.4 & \\
\hline & & & [89] & & 5.0 & \\
\hline & & M.M. $\mathrm{CH}_{4} \mathrm{C}$ & IPCC $2006^{\mathrm{a}}$ & Bottom-up & $1.09 \pm 0.17$ & $1.93 \pm 0.3$ \\
\hline & & & IPCC 2006 [36] & & 1.02 & \\
\hline & & & {$[89]$} & & 1.91 & \\
\hline \multirow[t]{4}{*}{ US } & 2009-2011 & Total Ivstk. $\mathrm{CH}_{4} \mathrm{C}$ & {$[90]$} & Top-down & $8.75-14.09$ & $6.83 \pm 1.05(2009)$ \\
\hline & & & [91] & Bottom-up & $6.82(2010) ; 6.77(2011)$ & $6.90 \pm 1.06(2011)$ \\
\hline & & & {$[12]$} & & 7.02 (2010); 6.97 (2011) & \\
\hline & & & [89] & & $6.97(2010) ; 6.91(2011)$ & \\
\hline \multirow[t]{4}{*}{ California } & 2013-2014 & Dairy cattle $\mathrm{CH}_{4} \mathrm{C}$ & IPCC 2006 & Bottom-up & $0.230 \pm 0.035$ & $0.382 \pm 0.058$ \\
\hline & & & [51] & Top-down & $0.603-1.06$ & \\
\hline & & All non-dairy Ivstk. $\mathrm{CH}_{4} \mathrm{C}$ & IPCC $2006^{\mathrm{a}}$ & Bottom-up & $0.15 \pm .022$ & $0.168 \pm 0.026(2013)$ \\
\hline & & & {$[51]$} & Top-down & $0.149-0.259$ & \\
\hline \multirow[t]{3}{*}{ California } & 2010 & Total Ivstk. $\mathrm{CH}_{4} \mathrm{C}$ & IPCC $2006^{\mathrm{a}}$ & Bottom-up & 0.38 & $0.54 \pm 0.08$ \\
\hline & & & [5, as analyzed in 22] & & 0.35 & \\
\hline & & & {$[22]$} & Top-down & 0.65 & \\
\hline \multirow[t]{3}{*}{ US } & 2008 & Total Ivstk. $\mathrm{CH}_{4} \mathrm{C}$ & [5, as analyzed in 23] & Bottom-up & 6.7 & $6.88 \pm 1.05$ \\
\hline & & & {$[12]$} & & 7.09 & \\
\hline & & & [23] & Top-down & $12.7 \pm 0.5$ & \\
\hline \multirow[t]{2}{*}{ Globe } & 2008 & E.F. $\mathrm{CH}_{4} \mathrm{C}$ & [Sum over all gridcells & Bottom-up & 75.12 & $77.82 \pm 11.91$ \\
\hline & & M.M. $\mathrm{CH}_{4} \mathrm{C}$ & from 5] & & 8.65 & $9.14 \pm 1.4$ \\
\hline \multirow[t]{3}{*}{ US } & 2004 & Total Ivstk. $\mathrm{CH}_{4} \mathrm{C}$ & IPCC $2006^{a}$ & Bottom-up & 5.5 & $6.42 \pm 0.98$ \\
\hline & & & {$[92]$} & & 5.8 & \\
\hline & & & {$[21]$} & Top-down & $9.15 \pm 0.98$ & \\
\hline
\end{tabular}

E.F. enteric fermentation, M.M. manure management

a Our calculations, using IPCC 2006 [4] Tier 1 regional emissions factors 
increasingly used anaerobic manure treatment lagoons, such as recent studies on dairy cattle emissions by Owen and Silver [52, 53].

Our estimates for the state of California result in livestock emissions of $0.540 \mathrm{~g} \mathrm{CH}_{4} \mathrm{C}$ in 2010 and $0.550 \mathrm{Tg} \mathrm{CH}_{4} \mathrm{C}$ in 2013, of which 0.165 and $0.177 \mathrm{Tg} \mathrm{CH}_{4} \mathrm{C}$ are due to dairy cattle manure management, respectively. California, however, utilizes anaerobic lagoon manure management systems at a higher rate than the US national average (59\% of manure is managed in anaerobic lagoons in California, compared to $34 \%$ for the US, based on state population-weighted values [50]). If we calculate emissions using the California manure management utilization rates in place of national average rates, California dairy cattle manure management emissions in 2010 and 2013 increase to 0.263 and $0.274 \mathrm{Tg} \mathrm{CH}_{4} \mathrm{C}$, bringing total California livestock emissions up to 0.638 and $0.647 \mathrm{Tg} \mathrm{CH}_{4} \mathrm{C}$ for 2010 and 2013, respectively. These totals approach Wecht et al.s value of $0.65 \mathrm{Tg} \mathrm{CH}_{4} \mathrm{C}$ for 2010 [22], but are well below the range of $0.752-1.32 \mathrm{Tg} \mathrm{CH}_{4} \mathrm{C}$ presented by Jeong et al. for 2013-2014 [51]. If we also employ MCF values from Owen and Silver's recent field observations of anaerobic lagoon manure management systems [52], California dairy cattle manure management emissions in 2010 and 2013 increase to 0.306 and $0.318 \mathrm{Tg} \mathrm{CH}_{4} \mathrm{C}$, respectively, bringing total emissions increase to 0.681 and $0.691 \mathrm{Tg} \mathrm{CH}_{4} \mathrm{C}$ in those years. These results show that our emissions estimates, if modified to reflect local conditions, are similar to or smaller than recent top-down estimates in California, where livestock and fossil fuelsector $\mathrm{CH}_{4}$ emissions are spatially well separated. The discrepancies between top-down and bottom-up estimates may arise from factors influencing either or both of the methods. Our estimates could be too low for several reasons, including underreported usage of anaerobic manure treatment lagoons, recent increases in local temperatures impacting emissions, and/or MCF values that are too low. Because our emissions factors were calculated at the regional level, it will remain important to modify them when characterizing localized emissions; this can be done by using the equations published by the IPCC [4] with the inputs provided here in Tables 1 and 2 , modified by relevant localized information such as manure management system utilization rates.

\section{Role of livestock $\mathrm{CH}_{4}$ in global atmospheric $\mathrm{CH}_{4}$ dynamics} In the early 2000s, annual increases in atmospheric $\mathrm{CH}_{4}$ concentrations temporarily flattened [24, 54]. After 2006, however, atmospheric $\mathrm{CH}_{4}$ concentration abruptly began to rise each year, and at the same time, its ${ }^{13} \mathrm{C}$ isotopic signature began to grow more negative [26, 27]. Several possible explanations are offered for the causes and geographical distribution of this renewal in growth. Bergamaschi et al. [55] find that annual $\mathrm{CH}_{4}$ emissions (from all sources) in 2007-2010 were 16-20 Tg larger than emissions in 2003-2005 period, with the increase mostly in the Northern and Southern tropics and Northern midlatitudes, and Nisbet et al. [25] indicate that global $\mathrm{CH}_{4}$ emissions (from all sources) were 15-22 Tg larger in 2010 than in 2005. Schaefer et al. [27] suggest that increases after 2007 are most likely from agricultural sources in the Northern hemisphere tropics and subtropics. In contrast, Nisbet et al. [26] suggest that these increases originate in the Southern hemisphere and Northern and Southern tropics, and are more likely due to wetland responses to meteorological conditions than agriculture, because of the abrupt step-change after 2006.

Our global estimates for annual livestock $\mathrm{CH}_{4}$ emissions are $118.0 \mathrm{Tg} \mathrm{CH}_{4}\left(88.5 \mathrm{Tg} \mathrm{CH}_{4} \mathrm{C}\right)$ in 2010, $11.7 \mathrm{Tg} \mathrm{CH}_{4}$ greater than 2003 emissions of 106.3 $\mathrm{Tg} \mathrm{CH}_{4}$ (79.7 $\mathrm{Tg} \mathrm{CH} \mathrm{CH}_{4} \mathrm{C}$ ). These quantities represent ca. one-fifth of total global methane emissions of 540-568 Tg $\mathrm{CH}_{4}$ year $^{-1}$ estimated for this time period by a suite of top-down inversions [14]. The $11.7 \mathrm{Tg} \mathrm{CH}_{4}$ year $^{-1}$ increase in annual livestock emissions reported here accounts for ca. one half to threefourths of the increases over this time period reported by Bergamaschi et al. [55] and Nisbet et al. [25]. These proportions support the idea that livestock $\mathrm{CH}_{4}$ emissions, while not the dominant overall source of global $\mathrm{CH}_{4}$ emissions, may be a major contributor to the observed increases in emissions in the 2000s to 2010s. As suggested by Saunois et al. [28], the importance of agricultural emissions in the global $\mathrm{CH}_{4}$ budget is highlighted by our results, which provide quantitative estimates with associated uncertainties. It is important to note, however, that our results cannot reveal any sharp changes from year-to-year, because we have imposed a linear transition from IPCC-based to revised coefficients over the years from 1990 to 2012; therefore, a larger magnitude of change over this time period is possible. In summing the changes in annual livestock $\mathrm{CH}_{4}$ emissions over time by latitude (Fig. 11; Table 6), we find that the largest increases are between $30 \mathrm{~N}$ and the equator (Northern tropics), potentially lending support to the conclusions of Schaefer et al. [27]. In the northern and southern tropics ( $30 \mathrm{~N}$ to equator and equator to $30 \mathrm{~S}$ ), our results are comparable to the results of multiple models reported by Bergamaschi et al. [Table 3 in 55]; whereas in higher latitudinal zones, the changes over time that we document are the same in sign but smaller in magnitude than the output of most of the inversions reported by those authors. These longitudinal patterns may improve future discernment of $\mathrm{CH}_{4}$ sources and dynamics over time. 


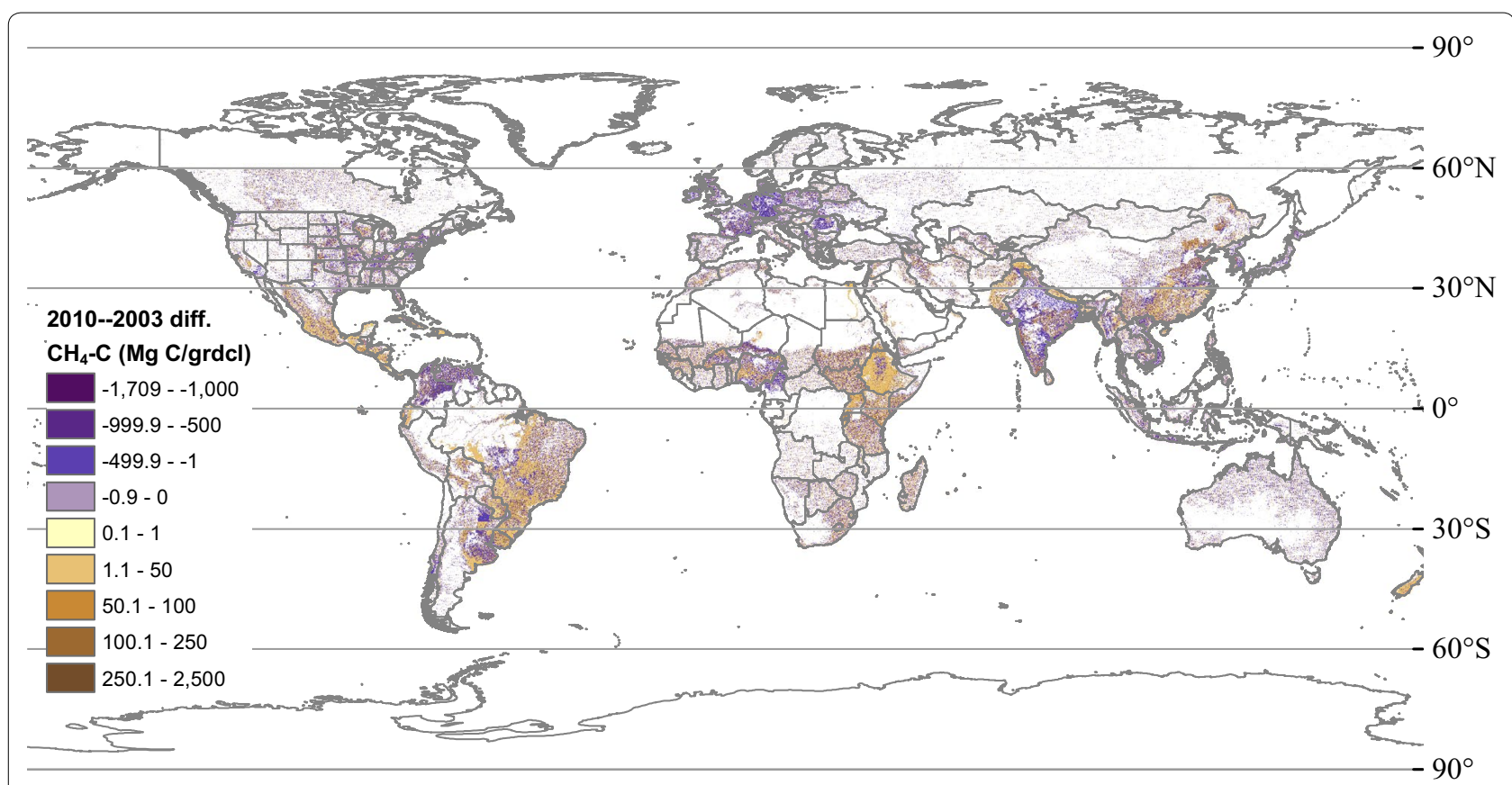

Fig. 11 Change in total livestock $\mathrm{CH}_{4}$ emissions between 2003 and 2010 (2010-2003 emissions), per $0.05 \times 0.05^{\circ}$ gridcell

Table 6 Temporal changes in annual livestock $\mathrm{CH}_{4}$ emissions by latitudinal zone

\begin{tabular}{|c|c|c|c|c|c|c|}
\hline Time period & $90 \mathrm{~N}-60 \mathrm{~N}$ & $60 N-30 N$ & $30 \mathrm{~N}$-equator & Equator-30S & $30 S-60 S$ & $60 \mathrm{~S}-90 \mathrm{~S}$ \\
\hline \multicolumn{7}{|c|}{$\mathrm{Tg} \mathrm{CH}_{4} \mathrm{C}_{\text {year }}{ }^{-1}$} \\
\hline 2003-2010 & $-0.08 \pm 0.15$ & $1.7 \pm 8.96$ & $5.18 \pm 9.87$ & $2.01 \pm 5.26$ & $-0.16 \pm 1.37$ & 0 \\
\hline 2000-2013 & $-0.12 \pm 0.16$ & $2.1 \pm 8.97$ & $5.59 \pm 9.39$ & $4.23 \pm 5.19$ & $0.28 \pm 1.34$ & 0 \\
\hline \multicolumn{7}{|l|}{$\mathrm{Tg} \mathrm{CH}_{4}$ year $^{-1}$} \\
\hline 2003-2010 & $-0.11 \pm 0.21$ & $2.27 \pm 11.95$ & $6.91 \pm 13.17$ & $2.69 \pm 7.02$ & $-0.21 \pm 1.83$ & 0 \\
\hline 2000-2013 & $-0.16 \pm 0.21$ & $2.8 \pm 11.97$ & $7.45 \pm 12.51$ & $5.64 \pm 6.92$ & $0.38 \pm 1.78$ & 0 \\
\hline
\end{tabular}

$\mathrm{Tg} \mathrm{CH}_{4} \mathrm{C}$ and $\mathrm{Tg}_{\mathrm{CH}}$ both shown to facilitate comparisons to other studies

\section{Limitations of revised emissions factors}

The revised per-animal emissions factors and/or total $\mathrm{CH}_{4}$ emissions reported here may differ from recent national self-reported emissions factors. This can be due to several factors, including (1) the inclusion of dairy calves and heifers with mature dairy cow populations, despite large differences in emissions between those groups, which can lead to low emissions factors; (2) interannual and sub-regional variation in diet and other factors. The revised emissions factors were developed for global analyses based on recent information, and the switch from IPCC 2006 was made linearly over a long time period (1990-2012) because information about their temporal dynamics was lacking. Therefore, variability at subregional and interannual scales are embedded in our estimates, and the revised emissions factors may not provide the best representation of emissions at local scales and/or for earlier years during the transition.

Emissions factors for poultry manure management $\mathrm{CH}_{4}$ were not revised in this study, but they should be reevaluated in future work. In the IPCC 2006 guidelines, poultry emissions factors for manure management are small (i.e. $<0.10 \mathrm{~kg} \mathrm{CH}_{4}$ per bird per year, except for laying hens with manure managed in lagoons). However, global poultry populations are large and continue to increase (Fig. 1b). Poultry manure management $\mathrm{CH}_{4}$ emissions are likely to be larger than estimated by IPCC 2006 guidelines for similar reasons as in cattle and swine: breeding has increased body sizes and growth rates [56] and utilization of liquid manure management systems is increasing [57]. 
The region of E. and SE Asia has proportionally less cattle and more swine than other regions of the world, making manure management of $\mathrm{CH}_{4}$ emissions much more prominent there (because swine do not have appreciable enteric fermentation emissions). The quantities of $\mathrm{CH}_{4}$ emitted from swine manure in this region, however, do have greater uncertainty. While the bulk of cattle manure in this region is collected and applied to cropland, particularly where cash crops are grown $[9,58-60]$, some of the manure produced by China's large swine population (ca. half of the world's total) is discharged to surface waters [61-64], and $\mathrm{CH}_{4}$ emissions have not been characterized for this situation. In this study, we considered emissions from manure discharged to surface waters to be similar to emissions from 'liquid and deep pit' treatments. If emission quantities from manure discharged to surface waters are more similar to emissions in anaerobic lagoons (i.e. liquid storage systems to combine waste stabilization and storage, in which solids are not removed more frequently than 15-20 years [65]), then the swine manure emissions factor may be as much as three times higher than the value used here.

In the Latin America region, meat cattle populations and their management practices are changing rapidly. In this region, our estimates of cattle on feedlots and other rapidly changing attributes may already be outdated [66], and frequent reassessment of this region will be warranted.

\section{US livestock $\mathrm{CH}_{4}$ emissions in recent decades}

Total $\mathrm{CH}_{4}$ emissions for the US and Canada show a slight but steady increase over recent decades despite decreasing populations of dairy cows and other cattle. This contrasts with W. Europe, where total emissions trajectories decline slightly in parallel with declines in livestock populations. The means exist to further reduce $\mathrm{CH}_{4}$ emissions, and they are available in the US and Canada (e.g. covered manure storage). The centralization of manure management in this region increases profitability but is also associated with increasing $\mathrm{CH}_{4}$ emissions, decreased potential for cropland application of manure, and other threats to common resources and public health $[7,61$, 67-69]. Studies examining the overall tradeoffs associated with increasing centralization vs. decentralization (e.g. potential $\mathrm{C}$ sequestration from manure application to cropland soils; $\mathrm{NOx}$ and $\mathrm{CH}_{4}$ emissions; costs of transportation for livestock, milk and meat, and manure; air and water quality; and impacts on rural communities such as odors and health risks) are needed. For example, if the efficiency of centralization outweighs other negative impacts, then capping lagoons to capture $\mathrm{CH}_{4}$ should be considered.

\section{Conclusions}

In this study, we found the revised bottom up estimates of $C$ fluxes and stocks from agricultural systems to be higher than those based on IPCC 2006 guidelines. The estimated global livestock $\mathrm{CH}_{4}$ emissions were $119.1 \pm 18.2 \mathrm{Tg}$ $\mathrm{CH}_{4}$ in year 2011; this quantity is $11 \%$ greater than that obtained using the IPCC 2006 emissions factors, encompassing an $8.4 \%$ increase in enteric fermentation $\mathrm{CH}_{4}$ and a $36.7 \%$ increase in manure management $\mathrm{CH}_{4}$, with notable variability among regions and sources. Likewise, the revised manure management $\mathrm{CH}_{4}$ emissions for year 2011 in the US were $71.8 \%$ higher than IPCC-based estimates, consistent with recently reported top-down estimates. Summing changes in annual livestock $\mathrm{CH}_{4}$ emissions geographically, by latitude and over time, we found that the largest increases over time were between $30 \mathrm{~N}$ and the equator (i.e. Northern tropics). Our results suggest that livestock $\mathrm{CH}_{4}$ emissions, while not the dominant overall source of global $\mathrm{CH}_{4}$ emissions, may be a major contributor to the recent increases in global $\mathrm{CH}_{4}$ emissions. The new regional and global $\mathrm{C}$ fluxes and stocks estimates improve the ability to reconcile top-down and bottomup estimates of $\mathrm{CH}_{4}$ production, and provide consistent estimates of $\mathrm{CH}_{4}$ emissions at the national, regional and global level, for use in development and evaluation of Earth system models and environmental assessments. The results reported here are useful to scientists and policy decision makers, given the importance of agricultural systems for food, fiber and bioenergy production, and their contributions to global methane emissions.

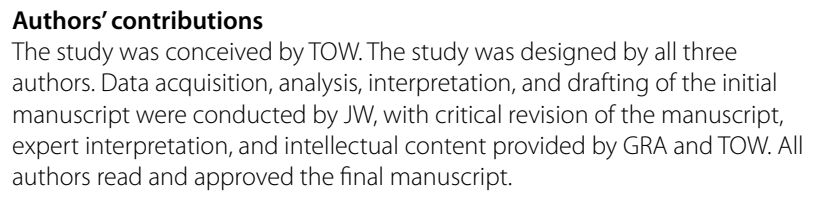

\section{Author details}

1 USDA-ARS, Adaptive Cropping Systems Laboratory, 10300 Baltimore Ave., Building 001, Room. 342, BARC-WEST, Beltsville, MD 20705, USA. ${ }^{2}$ Joint Global Change Research Institute, 5825 University Research Court, Suite 3500, College Park, MD 20740, USA. ${ }^{3}$ US Department of Energy, SC-23, 1000 Independence Ave., Washington, DC 20585, USA.

\section{Competing interests}

The authors declare that they have no competing interests.

\section{Availability of data and materials}

The results presented here can be recreated from the publicly available inventory and remote sensing data sources identified in the "Methods" section, in combination with the information provided in this manuscript's tables and text. The global gridded C flux data supporting the conclusions of this article are available online from Oak Ridge National Laboratory Distributed Active Archive Center at: http://daac.ornl.gov/cgi-bin/dsviewer.pl?ds_id=1329.

\section{Consent for publication}

Not applicable. 
Ethics approval and consent to participate

Not applicable.

\section{Funding}

This research was conducted with support from the National Aeronautics and Space Administration (NASA), Carbon Monitoring System (CMS) program under Project \#NNH13AW581.

\section{Publisher's Note}

Springer Nature remains neutral with regard to jurisdictional claims in published maps and institutional affiliations.

Received: 30 May 2017 Accepted: 16 August 2017

Published online: 29 September 2017

\section{References}

1. Herrero M, Havlík P, Valin H, Notenbaert A, Rufino MC, Thornton PK, et al. Biomass use, production, feed efficiencies, and greenhouse gas emissions from global livestock systems. Proc Natl Acad Sci USA. 2013;110:20888-93.

2. Wolf J, West TO, Le Page YL, Kyle GP, Zhang X, Collatz GJ, et al. Biogenic carbon fluxes from global agricultural production and consumption. Glob Biogeochem Cycles. 2015:29:1617-39.

3. Revised IPCC. IPCC guidelines for national greenhouse gas inventories, reference manual, vol. 3. Bracknell: Hadley Centre; 1996. p. 1996.

4. IPCC. 2006 IPCC guidelines for national greenhouse gas inventories, volume 4: agriculture, forestry and other land use. Kanagawa: Institute for Global Environmental Strategies; 2006. http://www.ipcc-nggip.iges.or.jp/ public/2006gl/vol4.html.

5. European Comission. Emission database for global atmospheric research (EDGAR), release version 4.2; 2010. http://edgar.jrc.ec.europa.eu.

6. Tubiello FN, Salvatore M, Rossi S, Ferrara A, Fitton N, Smith P. The FAOSTAT database of greenhouse gas emissions from agriculture. Environ Res Lett. 2013;8:015009.

7. MacDonald J, McBride W. The transformation of U.S. livestock agriculture: scale, efficiency, and risks. USDA Economic Research Service-EIB43. http:// www.ers.usda.gov/publications/eib-economic-information-bulletin/ eib43.aspx. Accessed 29 Jan 2014

8. MacDonald J, Ribaudo M, Livingston M, Beckman J, Huang W-Y. Manure use for fertilizer and for energy: report to congress USDA ERS-AP-037. USDA Economic Research Service; 2009. http://ers.usda.gov/publications/ap-administrative-publication/ap-037.aspx. Accessed 11 June 2015.

9. Xue $B$, Wang LZ, Yan T. Methane emission inventories for enteric fermentation and manure management of yak, buffalo and dairy and beef cattle in China from 1988 to 2009. Agric Ecosyst Environ. 2014;195:202-10

10. Gerber P, Vellinga T, Opio C, Henderson B, Steinfeld H. Greenhouse gas emissions from the dairy sector: a life cycle assessment. Rome: Food and Agriculture Organization Animal Production and Health Division; 2010.

11. Petersen SO, Blanchard M, Chadwick D, Del Prado A, Edouard N, Mosquera J, et al. Manure management for greenhouse gas mitigation animal. 2013;7:266-82.

12. EPA. Inventory of U.S. Greenhouse Gas Emissions and Sinks: 1990-2012. Washington: US Environmental Protection Agency, Climate Change Division Report No.: EPA 430-R-14-003. http://www.epa.gov/climatechange/ ghgemissions/usinventoryreport.html. Accessed Apr 2014

13. Kirschke S, Bousquet P, Ciais P, Saunois M, Canadell JG, Dlugokencky EJ, et al. Three decades of global methane sources and sinks. Nat Geosci. 2013;6:813-23.

14. Saunois M, Bousquet P, Poulter B, Peregon A, Ciais P, Canadell JG, et al. The global methane budget: 2000-2012. Earth Syst Sci Data Discuss. 2016;1-79.

15. Smith $P$, Bustamante $M$, Ahammad $H$, Clark $H$, Dong E, Elsiddig EA, et al. Agriculture, forestry and other land use (AFOLU). In: Edenhofer O, Pichs-Madruga R, Sokona Y, Farahani E, editors. Climate Change 2014 Mitigation Climate Change Contribution Work. Group III Fifth Assessment Report Intergovernmental Panel Climate Change. Cambridge: Cambridge University Press; 2014.
16. EPA. Global anthropogenic non- $\mathrm{CO}_{2}$ greenhouse gas emissions: 1990-2030. Washington: US EPA, Office of Atmospheric Programs, Climate Change Division; 2012. https://www3.epa.gov/climatechange/Downloads/EPAactivities/EPA_Global_NonCO2_Projections_Dec2012.pdf.

17. Höglund-Isaksson L. Global anthropogenic methane emissions 2005-2030: technical mitigation potentials and costs. Atmos Chem Phys. 2012:12:9079-96.

18. European Comission. EDGAR: the emissions database for global atmospheric research, part III: greenhouse gas emissions. 2012. http://edgar.jrc. ec.europa.eu/docs/IEA_PARTIII.pdf. Accessed 3 Nov 2016.

19. Dentener F, Stevenson D, Cofala J, Mechler R, Amann M, Bergamaschi $P$, et al. The impact of air pollutant and methane emission controls on tropospheric ozone and radiative forcing: CTM calculations for the period 1990-2030. Atmos Chem Phys. 2005;5:1731-55.

20. Turner AJ, Jacob DJ, Wecht KJ, Maasakkers JD, Lundgren E, Andrews AE, et al. Estimating global and North American methane emissions with high spatial resolution using GOSAT satellite data. Atmos Chem Phys. 2015:15:7049-69.

21. Wecht KJ, Jacob DJ, Frankenberg C, Jiang Z, Blake DR. Mapping of North American methane emissions with high spatial resolution by inversion of SCIAMACHY satellite data. J Geophys Res Atmos. 2014;119:7741-56.

22. Wecht KJ, Jacob DJ, Sulprizio MP, Santoni GW, Wofsy SC, Parker R, et al. Spatially resolving methane emissions in California: constraints from the CalNex aircraft campaign and from present (GOSAT, TES) and future (TROPOMI, geostationary) satellite observations. Atmos Chem Phys. 2014;14:8173-84.

23. Miller SM, Wofsy SC, Michalak AM, Kort EA, Andrews AE, Biraud SC, et al. Anthropogenic emissions of methane in the United States. Proc Natl Acad Sci. 2013:110:20018-22.

24. Kai FM, Tyler SC, Randerson JT, Blake DR. Reduced methane growth rate explained by decreased northern hemisphere microbial sources. Nature. 2011;476:194-7.

25. Nisbet EG, Dlugokencky EJ, Bousquet P. Methane on the rise-again. Science. 2014;343:493-5.

26. Nisbet EG, Dlugokencky EJ, Manning MR, Lowry D, Fisher RE, France JL, et al. Rising atmospheric methane: 2007-2014 growth and isotopic shift. Glob Biogeochem Cycles. 2016;30:1356-70.

27. Schaefer H, Fletcher SEM, Veidt C, Lassey KR, Brailsford GW, Bromley TM, et al. A 21 st-century shift from fossil-fuel to biogenic methane emissions indicated by 13CH4. Science. 2016;352:80-4

28. Saunois M, Jackson RB, Bousquet P, Poulter B, Canadell JG. The growing role of methane in anthropogenic climate change. Environ Res Lett. 2016;11:120207.

29. Manure management plan nutrient balance worksheet user guide. Penn State Extension; 2013. http://extension.psu.edu/plants/nutrient-management/manure/plan-writing/manure-management-plan-nutrientbalance-worksheet-user-guide. Accessed Apr 2017.

30. Müller DWH, Codron D, Meloro C, Munn A, Schwarm A, Hummel J, et al. Assessing the Jarman-Bell Principle: scaling of intake, digestibility, retention time and gut fill with body mass in mammalian herbivores. Comp Biochem Physiol A: Mol Integr Physiol. 2013;164:129-40.

31. Cattlemen's Beef Board and National Cattlemen's Beef Association. Explore beef-fact sheets: modern beef production; 2009. http://web. archive.org/web/20150511184326/, http://www.explorebeef.org/ cmdocs/explorebeef/factsheet_modernbeefproduction.pdf. Accessed 21 Jan 2017.

32. Speer N. Industry at a glance: placement weight trends indicate feedyards are feeding longer. Beef Mag. 2015. http://www.beefmagazine. com/feedlots/industry-glance-placement-weight-trends-indicate-feedyards-are-feeding-longer. Accessed 21 Jan 2017.

33. Indiana Agriculture Report. Great Lakes Region: USDA NASS; 2014. https://www.nass.usda.gov/Statistics_by_State/Indiana/Publications/ Ag_Report/2014/iar1411.pdf.

34. IPCC. Chapter 3: Uncertainties. In: Eggleston H, Buendia L, Miwa K, Ngara T, Tanabe K, editors. 2006 IPCC Guidelines National Greenhouse Gas Inventory vol. 1 General Guidelines Report. Kanagawa: Institute for Global Environmental Strategies; 2006. http://www.ipcc-nggip.iges.or.jp/ public/2006gl/vol1.html.

35. Taylor JR. An introduction to error analysis: the study of uncertainties in physical measurements. 2nd ed. Mill Valley: University Science Books; 1997. https://archive.org/details/TaylorJ.R.IntroductionToErrorAnalysis2ed. 
36. FAO. Food and Agriculture Organization of the United Nations Statistics Division (FAOSTAT). 2014. http://faostat.fao.org/. Accessed 1 Dec 2015.

37. USDA. Crop explorer for major crop regions. Foreign Agric Serv. 2011. http://www.pecad.fas.usda.gov/cropexplorer/. Accessed 1 Jan 2013.

38. FAO. Global livestock production and health atlas (GLiPHA). Food Agriculture Organisation United Nations Animal Production Health Division Global Livestock Production Health Atlas GLiPHA. 2014. http://kids.fao. org/glipha/. Accessed 1 Jan 2014.

39. USDA. Quickstats 2.0. National Agricultural Statistics Service. 2013. http:// quickstats.nass.usda.gov/. Accessed 26 Nov 2013.

40. Krausmann F, Erb K-H, Gingrich S, Lauk C, Haberl H. Global patterns of socioeconomic biomass flows in the year 2000: a comprehensive assessment of supply, consumption and constraints. Ecol Econ. 2008;65:471-87.

41. West TO, Le Page Y, Huang M, Wolf J, Thomson AM. Downscaling global land cover projections from an integrated assessment model for use in regional analyses: results and evaluation for the US from 2005 to 2095. Environ Res Lett. 2014;9:064004.

42. Bouwman AF, Van der Hoek KW, Eickhout B, Soenario I. Exploring changes in world ruminant production systems. Agric Syst. 2005;84:121-53.

43. Capehart T. Feed grains data: yearbook tables. USDA Economic Research Service; 2016. http://www.ers.usda.gov/data-products/feed-grains-database/feed-grains-yearbook-tables.aspx.

44. Renewable Fuels Association Co-Products. Historic distillers grains production from U.S. ethanol biorefineries. http://ethanolrfa.org/resources/ industry/co-products/\#1456865649440-ae77f947-734a. Accessed 8 Nov 2016.

45. Three factors led to 1996 grain price shock. Economic Daily US Bureau Labor Statistics. https://www.bls.gov/opub/ted/1998/nov/wk1/art01. htm. Accessed 6 Mar 2017.

46. Neuman W. Corn prices raise worry over expensive food. New York Times; 2010. http://www.nytimes.com/2010/10/13/business/13corn.html. Accessed 12 Oct 2010.

47. Lehmkuhler J, Burris W. Distillers grain coproducts for beef cattle. University of Kentucky; 2011. http://www2.ca.uky.edu/agcomm/pubs/asc/ asc186/asc186.pdf.

48. Hales KE, Cole NA, MacDonald JC. Effects of increasing concentrations of wet distillers grains with solubles in steam-flaked, corn-based diets on energy metabolism, carbon-nitrogen balance, and methane emissions of cattle. J Anim Sci. 2013;91:819-28.

49. Tian H, Lu C, Ciais P, Michalak AM, Canadell JG, Saikawa E, et al. The terrestrial biosphere as a net source of greenhouse gases to the atmosphere. Nature. 2016:531:225-8.

50. EPA. Inventory of U.S. greenhouse gas emissions and sinks: 1990-2013. Washington, DC: U.S. Environmental Protection Agency, Climate Change Division. http://www.epa.gov/climatechange/ghgemissions/usinventoryreport.html. Accessed Apr 2015

51. Jeong S, Newman S, Zhang J, Andrews AE, Bianco L, Bagley J, et al. Estimating methane emissions in California's urban and rural regions using multitower observations. J Geophys Res Atmos. 2016;121:2016JD025404.

52. Owen JJ, Silver WL. Greenhouse gas emissions from dairy manure management: a review of field-based studies. Glob Change Biol. 2015;21:550-65.

53. Owen JJ, Silver WL. Greenhouse gas emissions from dairy manure management in a Mediterranean environment. Ecol Appl. 2017;27:545-59.

54. Dlugokencky EJ, Houweling S, Bruhwiler L, Masarie KA, Lang PM, Miller JB, et al. Atmospheric methane levels off: temporary pause or a new steadystate? Geophys Res Lett. 2003;30:1992.

55. Bergamaschi P, Houweling S, Segers A, Krol M, Frankenberg C, Scheepmaker RA, et al. Atmospheric $\mathrm{CH} 4$ in the first decade of the 21st century: inverse modeling analysis using SCIAMACHY satellite retrievals and NOAA surface measurements. J Geophys Res Atmos. 2013;118:7350-69.

56. Tixier-Boichard M, Leenstra F, Flock DK, Hocking PM, Weigend S. A century of poultry genetics. Worlds Poult Sci J. 2012;68:307-21.

57. Poultry Manure Management Planning. West Lafayette: Purdue University Cooperative Extension Service and Indiana Soil Conservation Service; 1999. https://www.extension.purdue.edu/extmedia/ID/ID-206.html. Accessed Sep 1999.

58. Beldman ACG, Daatselaar CHG, Prins AM. Developments in dairying worldwide, from a dairy farmer's perspective. In: Rozstalnyy A, Rozstalnyy A, Keane G, editors. Cattle husbandry in Eastern Europe and China: structure, development paths optimisation. Wageningen: Wageningen Academic Publishers; 2014. p. 61-9.

59. Gao Z, Lin Z, Yang Y, Ma W, Liao W, Li J, et al. Greenhouse gas emissions from the enteric fermentation and manure storage of dairy and beef cattle in China during 1961-2010. Environ Res. 2014;135:111-9.

60. China beef and cattle production market 2013|China. 2015. http:// web.archive.org/web/20150318220516/, http://beforeitsnews.com/ china/2013/06/china-beef-and-cattle-production-market-2013-2446620. html. Accessed 18 Mar 2015.

61. Larson C. China's lakes of pig manure spawn antibiotic resistance. Science. 2015;347:704

62. McOrist S, Khampee K, Guo A. Modern pig farming in the People's Republic of China: growth and veterinary challenges. Revue Scientifique et Technique-OIE. 2011;30:961-8.

63. Mendoza Huaitalla R. Intensive pig production and manure management in Beijing, North China Plain; 2014. http://opus.uni-hohenheim.de/ volltexte/2014/972/. Accessed 15 May 2015.

64. Feeding China's pigs: implications for the environment, China's smallholder farmers and food security|Institute for Agriculture and Trade Policy; 2015. http://web.archive.org/web/20150318220942/, http://www. iatp.org/documents/feeding-china\%E2\%80\%99s-pigs-implications-forthe-environment-china\%E2\%80\%99s-smallholder-farmers-and-food. Accessed 18 Mar 2015.

65. Hamilton D. Lagoons for livestock waste treatment. Stillwater: Oklahoma Cooperative Extension Service. http://pods.dasnr.okstate.edu/docushare/ dsweb/Get/Document-7615/BAE-1736web2011.pdf.

66. What U.S. should know about South American beef productionprogressive cattleman. http://www.progressivecattle.com/topics/ management/6095-what-us-should-know-about-south-americanbeef-production. Accessed 9 Oct 2016.

67. Gurian-Sherman D. CAFOs uncovered the untold costs of confined animal feeding operations. Union of Concerned Scientists; 2008. http:// www.ucsusa.org/assets/documents/food_and_agriculture/cafos-uncovered.pdf.

68. Yang Q, Tian H, Li X, Ren W, Zhang B, Zhang X, et al. Spatiotemporal patterns of livestock manure nutrient production in the conterminous United States from 1930 to 2012. Sci Total Environ. 2016;541:1592-602.

69. National Conference of State Legislatures. Concentrated animal feeding operations. http://www.ncsl.org/research/agriculture-and-rural-development/concentrated-animal-feeding-operations.aspx. Accessed 27 Apr 2017.

70. United Nations Framework Convention on Climate Change. National Inventory Submissions; 2014. http://unfccc.int/national_reports/annex_i_ ghg_inventories/national_inventories_submissions/items/8108.php. Accessed 27 May 2017.

71. EEA (European Environment Agency). Annual European Union greenhouse gas inventory 1990-2012 and inventory report 2014-European Environment Agency (EEA). http://www.eea.europa.eu/publications/ european-union-greenhouse-gas-inventory-2014. Accessed 21 Apr 2015.

72. Madalena F, Peixoto M, Gibson J. Dairy cattle genetics and its applications in Brazil. LRRD Newsl. 2015. http://web.archive.org/ web/20150423220801/, http://www.Irrd.org//rrd24/6/made24097.htm.

73. de Leis CM, Cherubini E, Ruviaro CF, da Silva VP, do Nascimento Lampert $\mathrm{V}$, Spies A, et al. Carbon footprint of milk production in Brazil: a comparative case study. Int J Life Cycle Assess. 2015;20:46-60.

74. United Nations Framework Convention on Climate Change. Submitted National Communications from Non-Annex I Parties. http://unfccc.int/ national_reports/non-annex_i_natcom/items/10124.php. Accessed 27 May 2017.

75. Powell JM, MacLeod M, Vellinga TV, Opio C, Falcucci A, Tempio G, et al. Feed-milk-manure nitrogen relationships in global dairy production systems. Livest Sci. 2013;152:261-72.

76. Powell JM, Li Y, Wu Z, Broderick GA, Holmes BJ. Rapid assessment of feed and manure nutrient management on confinement dairy farms. Nutr Cycl Agroecosyst. 2008;82:107-15.

77. Duncan AJ, Teufel N, Mekonnen K, Singh VK, Bitew A, Gebremedhin B. Dairy intensification in developing countries: effects of market quality on farm-level feeding and breeding practices. Animal. 2013;7:2054-62.

78. Singhal K, Mohini M. Methane emission estimates from enteric fermentation in Indian livestock: dry matter intake approach. Curr Sci. 2005;88(1). 
79. Patra AK. Estimation of methane and nitrous oxide emissions from Indian livestock. J Environ Monit. 2012;14:2673-84.

80. Brazil: Livestock and products annual|USDA Foreign Agricultural Service. https://www.fas.usda.gov/data/brazil-livestock-and-products-annual-2. Accessed 29 May 2017.

81. Ten Years Later: a look at 10 years' worth of beef-production systems in South America. http://www.beefmagazine.com/foreign-trade/0401south-america-beef-production-systems. Accessed 29 May 2017.

82. Eastern Research Group, Inc., Tetra Tech, LOGICarbon. resource assessment for livestock and agro-industrial wastes_-Brazil. Global Methane Initiative; 2010. https://www.globalmethane.org/documents/ag_brazil_res_assessment.pdf.

83. Ji ZY, Cao Z, Liao XD, Wu YB, Liang JB, Yu B. Methane production of growing and finishing pigs in southern China. Anim Feed Sci Technol. 2011;166-167:430-5.

84. Eastern Research Group, Inc., Tetra Tech, LOGICarbon. Resource assessment for livestock and agro-industrial wastes_-India. Global Methane Initiative; 2010. https://www.globalmethane.org/documents/ag_brazil_res_assessment.pdf.

85. Huaitalla R, Gallmann E, Zheng K, Liu X, Hartung E. Pig husbandry and solid manures in a commercial pig farm in beijing, China. Int J Biol Biomol Agric Food Biotechnol Eng. 2010;4:217-26.
86. Wang F, Dou Z, Ma L, Ma W, Sims JT, Zhang F. Nitrogen mass flow in china's animal production system and environmental implications. J Environ Qual. 2010;39:1537.

87. Bai ZH, Ma L, Qin W, Chen Q, Oenema O, Zhang FS. Changes in pig production in China and their effects on nitrogen and phosphorus use and losses. Environ Sci Technol. 2014;48:12742-9.

88. EPA. Inventory of U.S. greenhouse gas emissions and sinks: 1990-2010. US EPA; 2012. https://www.epa.gov/ghgemissions/inventory-us-greenhouse-gas-emissions-and-sinks-1990-2010. Accessed 30 May 2017.

89. EPA. Inventory of U.S. greenhouse gas emissions and sinks: 1990-2014. US EPA; 2016. https://www.epa.gov/ghgemissions/ inventory-us-greenhouse-gas-emissions-and-sinks-1990-2014.

90. Turner AJ, Jacob DJ, Benmergui J, Wofsy SC, Maasakkers JD, Butz A, et al. A large increase in U.S. methane emissions over the past decade inferred from satellite data and surface observations. Geophys Res Lett. 2016;43:2218-24.

91. EPA. Inventory of U.S. greenhouse gas emissions and sinks: 1990-2011. Washington, DC: U.S. Environmental Protection Agency, Climate Change Division; 2013. http://www.epa.gov/climatechange/ghgemissions/usinventoryreport.html.

92. EPA. Inventory of U.S. greenhouse gas emissions and sinks: 1990-2006. US EPA; 2008. https://www.epa.gov/ghgemissions/inventory-us-greenhouse-gas-emissions-and-sinks-1990-2006. Accessed 30 May 2017.

\section{Submit your manuscript to a SpringerOpen ${ }^{\odot}$ journal and benefit from:}

- Convenient online submission

- Rigorous peer review

- Open access: articles freely available online

- High visibility within the field

- Retaining the copyright to your article

Submit your next manuscript at $\gg$ springeropen.com 